\title{
Azithromycin, a Lysosomotropic Antibiotic, Has Distinct Effects on Fluid-Phase and Receptor-Mediated Endocytosis, but Does Not Impair Phagocytosis in J 774 Macrophages
}

\author{
Donatienne Tyteca, ${ }^{* 1}$ Patrick Van Der Smissen,† Marcel Mettlen,† Françoise Van Bambeke,* \\ Paul M. Tulkens,* Marie-Paule Mingeot-Leclercq,* and Pierre J . Courtoyt ${ }^{2}$
}

*Unité de Pharmacologie Cellulaire et Moléculaire, Université Catholique de Louvain, UCL 7370 Avenue E. Mounier 73, B-1200 Brussels, Belgium; and †Unité de Biologie Cellulaire, Université Catholique de Louvain and Christian de Duve International Institute of Cellular and Molecular Pathology, UCL 7541 Avenue Hippocrate 75, B-1200 Brussels, Belgium

Pretreatment of J 774 mouse macrophages by the dicationic macrolide antibiotic, azithromycin (AZ), selectively inhibited fluid-phase endocytosis of horseradish peroxidase and lucifer yellow, but not phagocytosis of latex beads. AZ delayed sequestration of receptor-bound transferrin and peroxidase-anti-peroxidase immune complexes into cell-surface endocytic pits and vesicles, but did not slow down the subsequent rate of receptormediated endocytosis. AZ down-regulated cell surface transferrin receptors, but not $F \mathrm{c} \gamma$ receptors, by causing a major delay in the accessibility of internalized transferrin receptors to the recycling route, without slowing down subsequent efflux, resulting in redistribution of the surface pool to an intracellular pool. Acidotropic accumulation of $A Z$ was associated with an extensive vacuolation of late endosomes/ysosomes, and these compartments became unaccessible to horseradish peroxidase and immune complexes, but not to latex beads. The inhibitory profile of AZ cannot be solely accounted for by vacuolation and interference with acidification. AZ may help in dissecting various steps of the endocytic apparatus such as lateral mobility of receptors at the plasma membrane, formation of clathrin-independent endocytic vesicles, orientation of transferrin receptors into the recycling route, and fusogenicity with lysosomes. $\odot 2002$ Elsevier Science (USA)

Key Words: endocytosis; HRP; lucifer yellow; transferrin; immune complexes; phagocytosis; macrolide; macrophages.

\section{INTRODUCTION}

Endocytosis plays a central role in cell physiology and pathology [1-3]. The pathways followed by mate-

\footnotetext{
${ }^{1}$ Present address: Department of Membrane Cell Biology, Faculty of Medical Sciences, University of Groningen, Groningen, The Netherlands.

${ }^{2}$ To whom correspondence and reprint requests should be addressed. Fax: +32-2-764.75.43. E-mail: courtoy@cell.ucl.ac.be.
}

rials internalized by its three main modes (fluid-phase endocytosis, receptor-mediated endocytosis, and phagocytosis) have been amply delineated and the complexity of the underlying protein machineries and their interaction motives are becoming increasingly unraveled [4]. I n contrast, kinetic aspects of endocytosis have received comparatively less attention even though rate-limiting interactions between molecular actors and subcellular compartments are crucial for cell homeostasis and disease and their study is often illuminating [5- 8].

Dissection of the endocytosis machinery has greatly benefited from genetic approaches. These, however, have clear limitations. First, mutations affecting proteins involved in the regulation of endocytosis generally show pleiotropic effects and affect more than one specific route or step in endocytosis [9-15]. Multiplicity of effects possibly reflects the facts that (i) the overall function of the endocytic apparatus is coordinated, (ii) the same actors are involved at many steps, and/or (iii) interacting motives are being shared by more than one actor. Second, dominant-positive or -negative transfection does not equally affect all cells in a population and may trigger compensatory mechanisms [16]. Third, the effects of transfection can hardly be titrated and may be indirect [17]. Selective inhibitors of endocytosis that cause a rapid and uniform response and allow for titration of its effects ther efore remain of great interest. For example, drugs interfering with vacuolar acidification (e.g., chloroquine, monensin, or bafilomycin A1), affecting microtubules (e.g., nocodazole), or causing storage disorders such as phospholidosis have been instrumental in dissecting routes from endosomes to Iysosomes [7, 18-26]. With respect to the internalization step, the cholesterol-complexing agent, methyl- $\beta$ cyclodextrin, was shown to inhibit receptor-mediated endocytosis and, at higher concentrations, to affect bulk-phase endocytosis. When studied, drugs were 
shown to also affect regurgitation or phagocytosis [27-30].

Using primary cultures of rat fetal fibroblasts, we recently reported that the dicationic acid-stable macrolide antibiotic, azithromycin [31, 32], markedly inhibits fluid-phase uptake of horseradish peroxidase (HRP) and subsequent transfer to lysosomes, without affecting regurgitation [33]. It was also noticed that azithromycin caused an extensive vacuolation of late endocytic compartments. This prompted us to extend this analysis to receptor-mediated endocytosis and phagocytosis. For this purpose, we selected the established murine macrophage-like cell line, J 774, in which fluid-phase endocytosis, receptor-mediated endocytosis, and phagocytosis have all been extensively characterized [34-36]. The effects of azithromycin were addressed using (i) two classical and unrelated tracers of fluid-phase endocytosis, HRP and lucifer yellow (LY) [35, 37]; (ii) two validated and unrelated tracers of receptor-mediated endocytosis, transferrin [38] and peroxidase-anti-peroxidase immune complexes (PAP) $[39,40]$, that respectively explore constitutive internalization of the transferrin receptor followed by recycling vs ligand-induced entry of F c $\gamma$ receptor into the degradative pathway; and (iii) Texas red-labeled latex beads as a well-accepted tracer of phagocytosis [41].

Azithromycin was found (i) to inhibit fluid-phase endocytosis (HRP and LY) in a concentration-dependent manner; (ii) to down-regulate surface transferrin receptors and to delay the transfer of receptor-bound ligands (transferrin and PAP) into primary endocytic vesicles or the recycling route, but not to inhibit their subsequent rate of internalization or recycling per se; (iii) to impair the transfer of solutes taken up by fluidphase or receptor-mediated endocytosis into lysosomes; but (iv) not to affect phagocytosis nor fusion of phagosomes with lysosomes.

\section{MATERIALS AND METHODS}

Cell cultureand viability. The 774 macrophage cell line, derived from a mouse reticulosarcoma [42], was cultured in RPMI 1640 medium supplemented with $10 \%$ fetal calf serum (FCS). Unless stated otherwise, cells were seeded at $5.5 \times 10^{4}$ cells $/ \mathrm{cm}^{2}$ and grown until confluency ( 2 days) before exposure to $100 \mathrm{mg} / \mathrm{L}(132 \mu \mathrm{M})$ azithromycin for $3 \mathrm{~h}$. Cells were then washed and transferred to fresh medium containing the appropriate tracer but no azithromycin, since its effects lasted for at least $3 \mathrm{~h}$ after drug withdrawal (see Fig.2B). General toxicity was evaluated by cellular ATP level, plasma membrane integrity (release of lactate dehydrogenase), and DNA and protein syntheses, as described [33].

Fluid-phase endocytosis. HRP uptake and regurgitation were studied exactly as described earlier [33]. The same procedure was used for $L Y$, except that cells were washed three times for $30 \mathrm{~s}$ with PBS supplemented with $0.1 \%(\mathrm{w} / \mathrm{v})$ bovine serum al bumin (BSA) and four times with PBS (yielding a $99 \%$ release of $L Y$ bound to cells at $4^{\circ} \mathrm{C}$ ). U ptake of $L Y$ was measured on sonicated cell lysates prepared in $0.05 \%(\mathrm{v} / \mathrm{V})$ Triton $\mathrm{X}-100$ by fluorimetry (Perkin-EImer LS-30 fluorescence spectrophotometer; Beaconsfield, UK; $\lambda_{\text {exc }} 430 \mathrm{~nm}, \lambda_{\text {em }}$
$540 \mathrm{~nm}$ ). Since the uptake of both tracers proved strictly linear with their extracellular concentration in the range used, short-term experiments were performed at higher concentration than long-term studies. Values were then normalized to both cell protein content and to a nominal $1 \mathrm{mg} / \mathrm{ml}$ tracer concentration, in order to allow for direct comparison and provide equivalents to clearance values.

Receptor-mediated endocytosis. Iron-saturated transferrin was labeled by ${ }^{125}$ I with iodobeads [43] to a specific radioactivity of $800-$ $1300 \mathrm{cpm} / \mathrm{ng}$ of protein. Surface binding isotherm was determined after incubating cells precooled at $4^{\circ} \mathrm{C}$ with increasing concentrations of ${ }^{125} \mathrm{I}$-transferrin in FCS-free medium supplemented with $1 \%$ BSA for $1 \mathrm{~h}$, followed by three washes in ice-cold PBS- $\mathrm{Ca}^{2+}-\mathrm{Mg}^{2+}$ (PBS supplemented with $3.6 \mathrm{mM} \mathrm{CaCl}_{2}$ and $3 \mathrm{mM} \mathrm{MgSO}_{4}$ ). Radioactivity was measured in cell lysates prepared in $0.01 \%$ Triton X-100 (1275 Mini-Gamma counter; LKB Wallac, Sollentuna, Sweden). Nonspecific binding, estimated by incubating cells with a 300 -fold excess of cold transferrin, never exceeded $30 \%$ of the total cell-associated counts and was subtracted. For internalization studies, $50 \mathrm{nM}{ }^{125} \mathrm{I}$ transferrin was allowed to bind at $4^{\circ} \mathrm{C}$ for $1 \mathrm{~h}$, then cells were reincubated at $37^{\circ} \mathrm{C}$ in prewarmed medium without FCS but containing $1 \%$ BSA for the indicated intervals, followed by three washes at $4^{\circ} \mathrm{C}$ with PBS- $\mathrm{Ca}^{2+}-\mathrm{Mg}^{2+}$. Sensitivity to subsequent Pronase digestion ( $1 \mathrm{~h}$ at $4^{\circ} \mathrm{C} ; 3 \mathrm{mg} / \mathrm{ml}$ in $\mathrm{RPMI}$ ) was used to distinguish between surface-accessible vs intracellular transferrin [5]; this method removed $96.6 \%$ of the amount bound at $4^{\circ} \mathrm{C}$ to untreated cells, but up to $99.7 \%$ for azithromycin-treated cells. Recycling of ${ }^{125} \mathrm{I}$-transferrin was studied after binding at $4^{\circ} \mathrm{C}$, internalization in transferrin-free medium for $3 \mathrm{~min}$ at $37^{\circ} \mathrm{C}$, washing at $4^{\circ} \mathrm{C}$, and reincubation in transferrin-free medium at $37^{\circ} \mathrm{C}$ for up to $60 \mathrm{~min}$, as described [23].

For binding and internalization of PAP immune complexes, the same procedure was used, except that (i) binding at $4^{\circ} \mathrm{C}$ was extended for $2 \mathrm{~h}$, (ii) nonspecific binding at $4^{\circ} \mathrm{C}$ was measured by competition with a 100-fold mass ( $\sim 250$-fold molar) excess of mouse IgG, and (iii) surface-accessible was distinguished from internalized ligand upon subsequent displacement by excess mouse IgG at $4^{\circ} \mathrm{C}$ for $1 \mathrm{~h}$ (yielding $90 \%$ removal of the material initially bound at $4^{\circ} \mathrm{C}$ ). Attempts at surface digestion with Pronase $(3 \mathrm{mg} / \mathrm{ml})$, trypsin (1 $\mathrm{mg} / \mathrm{ml}$ ), bromelain $(3 \mathrm{mg} / \mathrm{ml})$, or acid stripping at $\mathrm{pH} 3.0$ proved ineffective if performed at $4^{\circ} \mathrm{C}$.

Phagocytosis of latex beads. Cells were incubated at $37^{\circ} \mathrm{C}$ with carboxylate-modified latex beads of two different sizes covalently coupled to Texas red ( 1 and $0.1 \mu \mathrm{m}$ in diameter). After five washes for $30 \mathrm{~s}$ with PBS at $4^{\circ} \mathrm{C}$ (removing more than $90 \%$ of the beads bound at $4^{\circ} \mathrm{C}$ ), uptake of beads was measured on sonicated cell lysates by fluorimetry ( $\lambda_{\text {exc }} 575 \mathrm{~nm} ; \lambda_{\text {em }} 610 \mathrm{~nm}$ ).

Western blotting. Washed cells were lysed in $0.5 \%(\mathrm{w} / \mathrm{v})$ sodium deoxycholate, $0.1 \%(\mathrm{w} / \mathrm{v})$ SDS, and $1 \%(\mathrm{v} / \mathrm{v})$ nonionic detergent (I ge pal CA-630) in the presence of protease inhibitors (phenylmethylsulfonyl fluoride, aprotinin, and sodium orthovanadate), resolved by SDS-PAGE under denaturing and reducing conditions (NuPAGE antioxidant), and analyzed by standard Western blotting procedures, using blocking in $1 \%(\mathrm{w} / \mathrm{v})$ nonfat milk and $0.025 \%(\mathrm{v} / \mathrm{v})$ Tween 20 , overnight incubation at $4^{\circ} \mathrm{C}$ with mouse anti-human transferrin receptor monoclonal antibody (cross-reacting with the murine transferrin receptor; 1:250), followed by anti-mouse HRP-conjugated secondary antibodies (1:750) and revealed by chemiluminescence (ECL kit; Amersham, Buckinghamshire, UK).

Other biochemical assays. Proteins were measured by the Lowry procedure. Azithromycin was assayed by a disc-plate microbiological technique, as described in Montenez et al. [44]. Because of the large accumulation of azithromycin in cells (see Results), we checked that a 10-fold excess of drug in the final assay mixtures over that contributed by lysates from treated cells caused no interference in all biochemical assays. Chloroquine was assayed on sonicated cell lysates by fluorimetry ( $\lambda_{\text {exc }} 335 \mathrm{~nm} ; \lambda_{\mathrm{em}} 378 \mathrm{~nm}$ ) after precipitation of 
TABLE 1

Assessment of Cell Integrity and Overall Functionality

\begin{tabular}{|c|c|c|}
\hline & Control & Azithromycin \\
\hline ATP content ${ }^{\mathrm{a}}\left(\mathrm{nmol} \cdot \mathrm{mg}\right.$ cell protei $\left.^{-1}\right)$ & $22.8 \pm 3.0$ & $24.9 \pm 2.5$ \\
\hline LDH release in medium $(\%$ of total $)$ & $1.3 \pm 0.5$ & $1.2 \pm 0.2$ \\
\hline$\left[{ }^{3} \mathrm{H}\right]$ Leucine incorporation ${ }^{\mathrm{b}}$ (TCA insoluble; \% of total cell counts) & $95.9 \pm 0.3$ & $95.3 \pm 0.2$ \\
\hline$\left[{ }^{3} \mathrm{H}\right]$ Thymidine incorporation ${ }^{\mathrm{b}}$ (TCA insoluble; \% of total cell counts) & $98.4 \pm 0.0$ & $97.0 \pm 0.2$ \\
\hline
\end{tabular}

\footnotetext{
${ }^{a}$ Cells were pretreated with $100 \mathrm{mg} / \mathrm{L}$ azithromycin $(132 \mu \mathrm{M})$ for $3 \mathrm{~h}$.

${ }^{\mathrm{b}}$ Cells were further pulse-labeled with $70 \mathrm{nM}\left[{ }^{3} \mathrm{H}\right]$ leucine or $120 \mathrm{nM}\left[{ }^{3} \mathrm{H}\right]$ thymidine for $3 \mathrm{~h}$ in the presence of azithromycin; total cell-associated label was $21.8 \pm 0.5 \mathrm{vs} 19.4 \pm 1.3 \mathrm{pmol}$ of $\left[{ }^{3} \mathrm{H}\right]$ leucine $\cdot \mathrm{mg}$ cell protein ${ }^{-1}$ and $324 \pm 7 \mathrm{vs} 297 \pm 17 \mathrm{pmol}$ of $\left[{ }^{3} \mathrm{H}\right]$ thymidine $\cdot \mathrm{mg}$ cell protein ${ }^{-1}$, in control vs treated cells, respectively.
}

proteins with trichloroacetic acid and addition of $\mathrm{NaOH}$ to reach $\mathrm{pH}$ 10 (adapted from [45]).

Immunolabeling of transferrin and Fcy receptors. To analyze well-individualized cells, confocal microscopy studies were performed on J 774 macrophages seeded at lower density $\left(1.3 \times 10^{4}\right.$ cells $/ \mathrm{cm}^{2}$ ) than for other experiments. Cells were fixed with $4 \%$

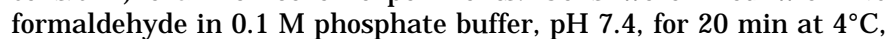
washed with PBS- $\mathrm{Ca}^{2+}-\mathrm{Mg}^{2+}$, and permeabilized with $0.05 \%(\mathrm{w} / \mathrm{v})$ saponin in PBS for $10 \mathrm{~min}$. Nonspecific sites were blocked with $1 \%$ BSA, $0.1 \%$ lysine, $0.01 \%$ saponin, and $0.02 \%$ sodium azide in PBS (Q-PBS) for $30 \mathrm{~min}$. Cells were then incubated for $1 \mathrm{~h}$ with a mouse monoclonal antibody directed against the human transferrin receptor $(0.5 \mu \mathrm{g} / \mathrm{ml})$ or a rat monoclonal antibody directed against mouse Fc $\gamma$ receptor $(5 \mu \mathrm{g} / \mathrm{ml}$ ). After six washes of 5 min each with Q-PBS, cells were incubated for $30 \mathrm{~min}$ with $5 \mu \mathrm{g} / \mathrm{ml}$ of the appropriate secondary antibodies (Alexa Fluor 488-anti-mouse IgG and Alexa Fluor 568-anti-rat IgG), washed again six times for $5 \mathrm{~min}$ each in PBS, postfixed for $5 \mathrm{~min}$ with $4 \%$ formaldehyde in $0.1 \mathrm{M}$ phosphate buffer, washed three times in PBS, and mounted in polyvinyl alcohol/ diazabicyclo[2.2.2]octane (Mowiol/DABCO) overnight. Immunofluorescence localization was performed with MRC1024 confocal scanning equipment (Bio-Rad, Richmond, CA) mounted on a Zeiss Axiovert confocal microscope (Zeiss, Oberkochen, Germany; $\lambda_{\text {exc }} 495$ and $\lambda_{\text {em }} 519 \mathrm{~nm}$ for transferrin receptor; $\lambda_{\text {exc }} 578 \mathrm{~nm}, \lambda_{\text {em }} 603 \mathrm{~nm}$ for Fc $\gamma$ receptor).

Peroxidase cytochemistry and ultrastructural microscopy. These were performed exactly as described [33].

Confocal imaging of living cells. Fluid-phase endocytosis, receptor-mediated endocytosis, and phagocytosis were tracked in living cells using $1 \mathrm{mg} / \mathrm{ml}$ rhodamine-HRP, $10 \mathrm{mg} / \mathrm{ml}$ Alexa Fluor 568PAP immune complexes, and 2500 beads/ $\mu$ l Texas red-labeled beads (0.1 $\mu \mathrm{m}$ in diameter), respectively. Vital labeling of acidic organelles was achieved by incubation with $75 \mathrm{nM}$ LysoTracker green (Green DND-26). Cells were washed in ice-cold PBS- $\mathrm{Ca}^{2+}-\mathrm{Mg}^{2+}$ containing LysoTracker green and immediately examined by confocal microscopy (with the following $\lambda_{\text {exc }}$ and $\lambda_{\text {em }}$ : LysoTracker green, 504 and 511 $\mathrm{nm}$; rhodamine-HRP, 580 and $605 \mathrm{~nm}$; Alexa 568-PAP, 578 and 603 $\mathrm{nm}$; Texas red latex beads, 575 and $610 \mathrm{~nm}$ ).

Materials. Azithromycin (dihydrate free base for microbiological standard; 94\% purity) was generously supplied by Pfizer S.A. (Brussels, Belgium) on behalf of Pfizer, Inc. (Groton, CT). The drug was dissolved in $0.1 \mathrm{~N} \mathrm{HCl}$ at $30 \mathrm{mM}(22.5 \mathrm{mg} / \mathrm{ml}$; stock solution) and thereafter diluted in the culture medium to the desired final concentrations. Aprotinin, carboxylate-modified polystyrene latex beads covalently coupled to Texas red, chloroquine, DABCO, diaminobenzidine, holotransferrin, horseradish peroxidase type II, I gepal CA-630, lucifer yellow $\mathrm{CH}$, mouse IgG, o-dianisidine, phenylmethylsulfonyl fluoride, rhodamine-HRP, sodium deoxycholate, sodium orthovanadate, and thimerosal were from Sigma-Aldrich (St. Louis, MO). LysoTracker Green DND-26, Alexa Fluor 568 protein labeling kit,
Alexa Fluor 488-anti-mouse IgG, and Alexa Fluor 568-anti-rat IgG were from Molecular Probes (Eugene, OR); Pronase and ATP bioluminescence kit were from Roche Diagnostics (Mannheim, Germany); PAP immune complexes and HRP-conjugated anti-mouse secondary antibodies were from Dako (Glostrup, Denmark); monoclonal mouse anti-human transferrin receptor antibodies were from Zymed (South San Francisco, CA); rat anti-mouse Fcy III/II receptor monoclonal antibodies were from Pharmingen (San Diego, CA); NuPAGE products for Western blotting were from Invitrogen/Life Technologies (Carlsbad, CA); Mowiol 4-88 was from Calbiochem (La J olla, CA); iodobeads for ${ }^{125}$ I-labeling were from Pierce (Rockford, IL); $\mathrm{Na}^{125}$ I, $\mathrm{L}-\left[4,5-{ }^{3} \mathrm{H}\right]$ leucine and [methyl $\left.-{ }^{3} \mathrm{H}\right]$ thymidine were from Amersham Pharmacia (Piscataway, NJ). Other reagents were from E. Merck (Darmstadt, Germany). Culture sera and media were supplied by Life Technologies (Paisley, UK).

Reproducibility and statistical analyses. All values shown are means \pm SD of three dishes (where not visible, error bars are included in the symbols). The number of experiments is indicated in figure legends. Statistical comparisons of experimental values (by the Student $t$ test) and other mathematical analyses were performed with the GraphPad InStat software [version 3.00; GraphPad Software, San Diego, CA (http://www.graphpad.com)]. Differences were considered significant at $\mathrm{P}<0.05$.

\section{RESULTS}

\section{Azithromycin Does Not Cause Overall Toxicity in J 774 Mouse Macrophages}

Table 1 shows that azithromycin at $100 \mathrm{mg} / \mathrm{L}$ (132 $\mu \mathrm{M}$ ) caused no significant change in ATP cell content, LDH release, or $\left[{ }^{3} \mathrm{H}\right]$ leucine and $\left[{ }^{3} \mathrm{H}\right]$ thymidine incorporation after a 3 -h preincubation. These conditions were therefore used for most subsequent experiments.

\section{Azithromycin Severely I nhibits Fluid-Phase Endocytosis in J 774 Macrophages}

It was first verified that both HRP and LY satisfied the basic criteria for tracers of fluid-phase endocytosis in J 774 macrophages. These criteria included: (i) a strictly linear accumulation over a large range of concentrations (up to $4 \mathrm{mg} / \mathrm{ml}$ for HRP and $3 \mathrm{mg} / \mathrm{ml}$ for LY) and intersecting the ordinate exactly at its origin, (ii) a constant rate of accumulation (up to at least $4 \mathrm{~h}$ ), and (iii) an apparent clearance at steady state (long- 
口, 匹 HRP ; $\triangle, \Delta$ lucifer yellow

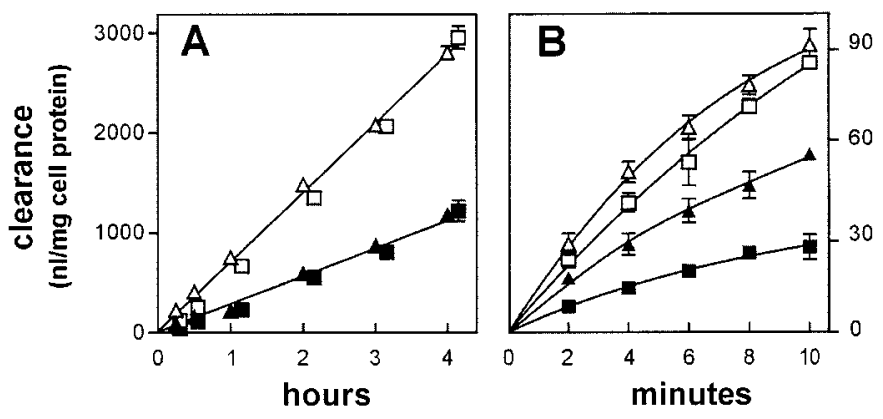

FIG. 1. Effect of azithromycin on the clearance of the fluid-phase endocytosis tracers, horseradish peroxidase ( $2 \mathrm{mg} / \mathrm{ml} \mathrm{HRP}$ ) and lucifer yellow ( $1 \mathrm{mg} / \mathrm{ml}$ LY), in $\mathrm{J} 774$ mouse macrophages. Cells were either left untreated (open symbols) or pretreated with $100 \mathrm{mg} / \mathrm{L}$ (132 $\mu \mathrm{M}$ ) azithromycin for $3 \mathrm{~h}$ (filled symbols). (A) Long-term exposure. (B) Short-term exposure. Values are normalized to a nominal 1 $\mathrm{mg} / \mathrm{ml}$ tracer concentration. All data in this and subsequent figures are the means \pm SD of three dishes (where not visible, error bars are included in the symbols). All differences between untreated and azithromycin-treated cells are significant $(P<0.05)$. Experiments were reproduced three times with similar results.

term accumulation) indistinguishable for both tracers $\left(11.2 \pm 1.6\right.$ and $11.4 \pm 1.3 \mathrm{nl} \cdot \mathrm{min}^{-1} \cdot \mathrm{mg}$ cell protein ${ }^{-1}$; $\mathrm{n}=4$; NS; this value is comparable to that reported in the same cells for LY [35]).

Figure 1A shows that pretreatment with $100 \mathrm{mg} / \mathrm{L}$ azithromycin for $3 \mathrm{~h}$ markedly impaired endocytosis of both tracers (clearance decreased by $\sim 70 \%$ at any time between $15 \mathrm{~min}$ and $4 \mathrm{~h}$ for a given concentration). After $2 \mathrm{~h}$ of tracer uptake, the same level of inhibition was seen over the entire range of concentration investigated $(0.5-4 \mathrm{mg} / \mathrm{ml}$ for HRP and $0.5-3 \mathrm{mg} / \mathrm{ml}$ for $\mathrm{LY}$; data not shown). After shorter times of uptake $(<15$ $\mathrm{min}$ ), i.e., when the regurgitated fraction is still incomplete [5], both tracers showed in control cells a faster apparent clearance, even slightly faster for LY than for HRP measured strictly in parallel (Fig. 1B), consistent with the molecular size fractionation mechanism analyzed in detail by Berthiaume et al. [6]. Figure 1B further shows that azithromycin also inhibited this early uptake (by $\sim 65 \%$ for HRP and $\sim 40 \%$ for LY at 2 $\mathrm{min})$. The observation that very short- and long-term accumulation were both inhibited by azithromycin argues against an indirect effect due to primary acceleration of regurgitation. To further exclude this possibility, cells were loaded with HRP or LY for 15 min and then allowed to release the tracers in fresh medium for up to $60 \mathrm{~min}$. The rate of efflux of both tracers was not significantly affected by azithromycin (data not shown).

Figure 2 shows that the effect of azithromycin on HRP endocytosis was almost strictly linearly related to its intracellular content, as previously observed with fibroblasts [33] (this cellular content being itself di- rectly proportional to the extracellular concentration, data not shown). Upon transfer of cells into drug-free medium, azithromycin release started rapidly but inhibition of HRP persisted for $3 \mathrm{~h}$, after which it showed a delayed decrease that paralleled the loss of intracellular drug content (Fig. 2B). This observation explains why it was possible to assess the influence of azithromycin on fluid-phase endocytosis at $\sim 3 \mathrm{~h}$ after drug removal and allowed us to further rule out a direct effect of extracellular azithromycin by systematically performing all endocytosis/phagocytosis assays after $3 \mathrm{~h}$ azithromycin pretreatment followed by a 1- to 3-h postincubation in drug-free medium.

Additional experiments (data not shown) disclosed that (i) the inhibition of the endocytic uptake of both HRP and LY was maximal after $1 \mathrm{~h}$ of exposure to azithromycin and remained constant for up to $24 \mathrm{~h}$ of pretreatment with the drug, and (ii) no inhibition was seen if cells were pretreated with azithromycin together with $20 \mu \mathrm{M}$ monensin, a condition that almost entirely abrogated the cellular accumulation of azithromycin.

\section{Azithromycin Severely Down-regulates Surface \\ Transferrin Receptors, Slightly Delays \\ Internalization of Transferrin, and Markedly \\ Delays Its Recycling in J 774 Macrophages}

To address the effect of azithromycin on constitutive receptor-mediated endocytosis and recycling, transferrin uptake and efflux were studied. As shown in Fig. $3 \mathrm{~A},{ }^{125} \mathrm{I}$-transferrin binding at $4^{\circ} \mathrm{C}$ to untreated J 774 macrophages reached saturation at $\sim 1200 \mathrm{fmol} \cdot \mathrm{mg}$ cell protein $^{-1}$, corresponding to $\sim 75,000$ binding sites $\cdot$ cell $^{-1}$ with a single class of receptors exhibiting
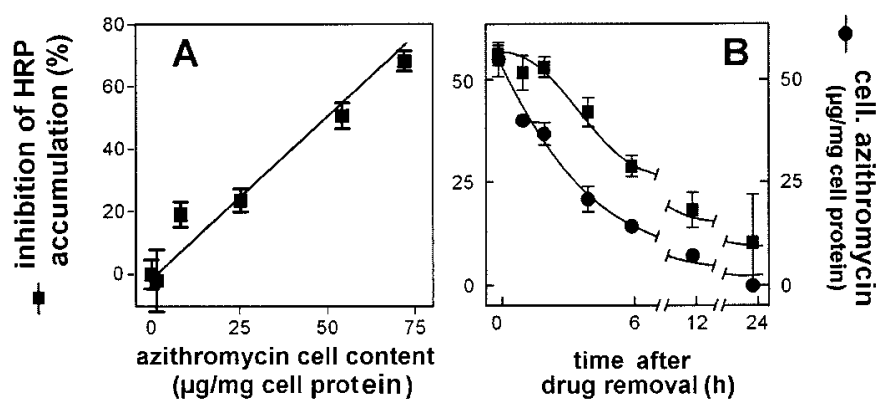

FIG. 2. (A) Correlation between inhibition of HRP endocytosis and azithromycin cell content in $\mathbf{J} 774$ macrophages in cells pretreated at increasing concentrations of azithromycin for $3 \mathrm{~h}$ and then challenged with HRP for $2 \mathrm{~h}$ in the absence of drug. (B) Persistence of the effect of a pretreatement with azithromycin on the inhibition of HRP uptake. Cells were pretreated with $100 \mathrm{mg} / \mathrm{L}$ azithromycin for $3 \mathrm{~h}$, transferred to drug-free medium for the indicated times, and then challenged with HRP for $2 \mathrm{~h}$ without azithromycin; cell lysates were assayed in parallel for peroxidase activity (filled squares) and azithromycin content (filled circles). Experiments were reproduced three times with similar results. 


\section{transferrin}
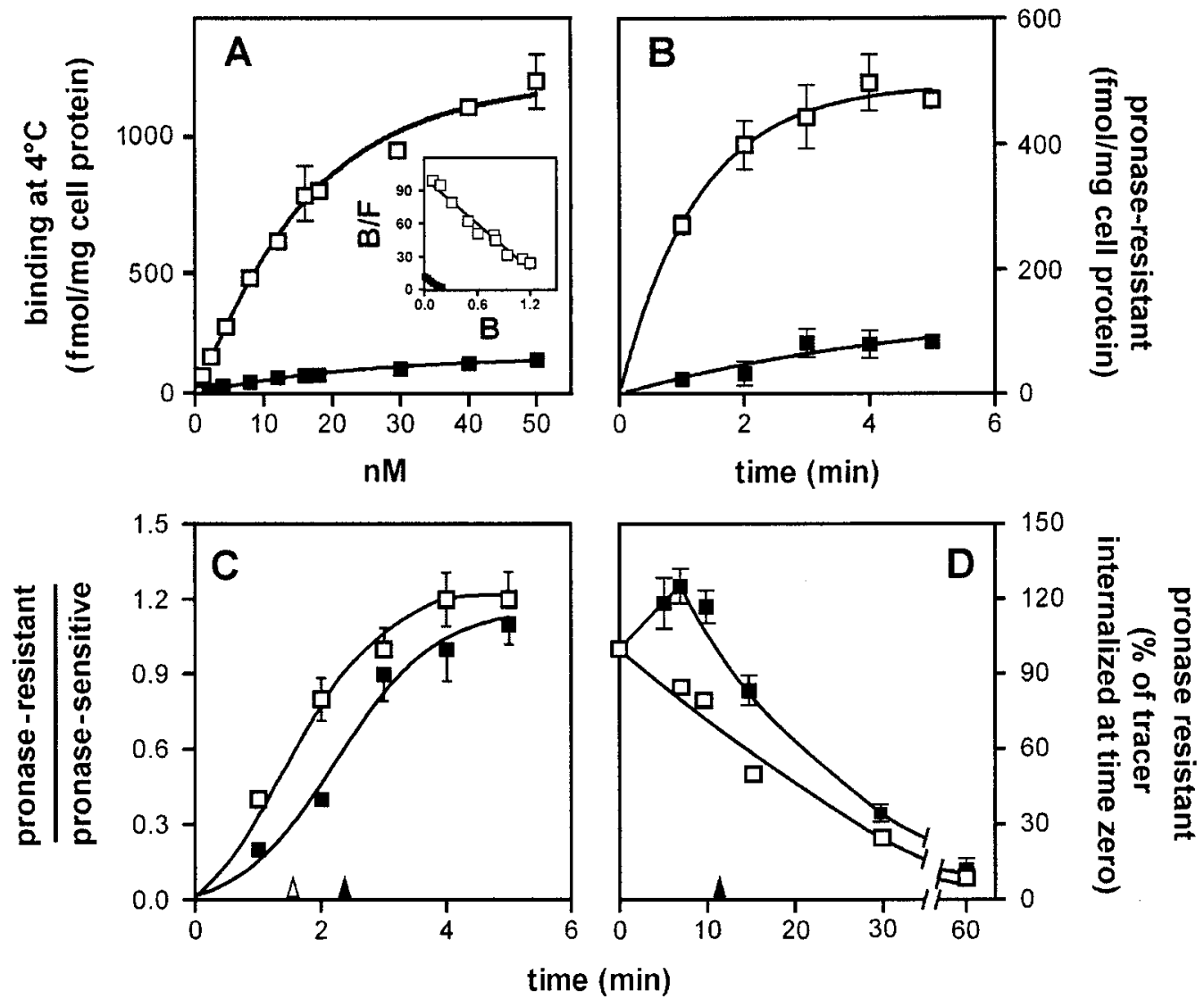

FIG. 3. Effect of azithromycin on ${ }^{125} \mathrm{I}$-transferrin binding and processing by $\mathrm{J} 774$ macrophages. Cells were either left untreated (open squares) or pretreated with $100 \mathrm{mg} / \mathrm{L}$ azithromycin for $3 \mathrm{~h}$ (filled squares). (A) Specific binding isotherms of ${ }^{125} \mathrm{I}$-transferrin at $4^{\circ} \mathrm{C}$ (nonspecific binding, measured with excess cold transferrin, was subtracted). Inset, Scatchard plot of the same data (bound values in abscissa are in $\mathrm{pmol} / \mathrm{mg}$ cell protein; bound/free ratios in the ordinate are in $\mu \mathrm{l} / \mathrm{mg}$ cell protein). (B) Kinetics of ${ }^{125}$ I-transferrin internalization. Cells were surface-labeled with $50 \mathrm{nM}{ }^{125} \mathrm{I}$-transferrin at $4^{\circ} \mathrm{C}$, washed, and reincubated at $37^{\circ} \mathrm{C}$ in tracer-free medium for the indicated times, after which Pronase-resistant counts were taken as a measure of intracellular ligand. (C) Efficiency of ${ }^{125}$ I-transferrin internalization, expressed as ratio of Pronase-resistant (surface-sequestered and intracellular) vs sensitive counts (surface-accessible) with increasing times of incubation at $37^{\circ} \mathrm{C}$; time for half-internalization is indicated by an open (control) and a filled arrowhead (treated cells); note the essentially parallel but delayed (by $\sim 0.5 \mathrm{~min}$ ) internalization in azithromycin-treated cells. (D) Loss of ${ }^{125}$ I-transferrin by recycling; after 3 min internalization as in C, cells were reincubated for the indicated times in fresh medium and Pronase-resistant counts were measured and expressed as a percentage of tracer internalized after $3 \mathrm{~min}$; the filled arrowhead indicates the delay at which intracellular ${ }^{125}$-transferrin in treated cells reaches again initial values at the beginning of the chase; note that values above $100 \%$ indicate that more ${ }^{125}$-transferrin was further internalized from the cell surface than recycled at this time interval. Experiments shown in B, C, and D were reproduced three times with similar results.

an apparent $\mathrm{K}_{\mathrm{d}}$ of $\sim 15 \mathrm{nM}$, based on Scatchard plot analysis. To study endocytosis and recycling with maximal sensitivity, cells were surface-labeled with $50 \mathrm{nM}$ ${ }^{125} \mathrm{I}$-transferrin, washed, and reincubated at $37^{\circ} \mathrm{C}$ for the indicated intervals, after which they were transferred to $4^{\circ} \mathrm{C}$ and surface-digested with Pronase to distinguish the pool accessible at the plasma membrane (Pronase-sensitive) from the sequestered pool (Pronase-resistant) [46]. Pronase-resistant transferrin increased very rapidly to level off after $\sim 4 \mathrm{~min}$ (Fig. 3B). The ratio of Pronase-resistant to Pronase-sensitive counts, an index of internalization efficiency [47], illustrates how fast surface-bound ${ }^{125} \mathrm{I}$-transferrin was internalized in $\mathrm{J} 774$ cells (>60\% in 2 min; Fig. 3C), with an apparent equilibrium between the rapidly recycling pool and the plasma membrane pool being reached after $\sim 4 \mathrm{~min}$ at a ratio of 1.2. Figure 3D shows that total internalized ${ }^{125} \mathrm{I}$-transferrin is recycled from the combined rapidly and slowly recycling pools with a half-time of $\sim 18 \mathrm{~min}$.

Azithromycin treatment caused a dramatic decrease in the surface pool of transferrin-receptors, down to $\sim 20 \%$ of control (Fig. 3A), without detectable difference in apparent affinity (no significant change in $\mathrm{K}_{\mathrm{d}}$ 


\section{immune complexes}
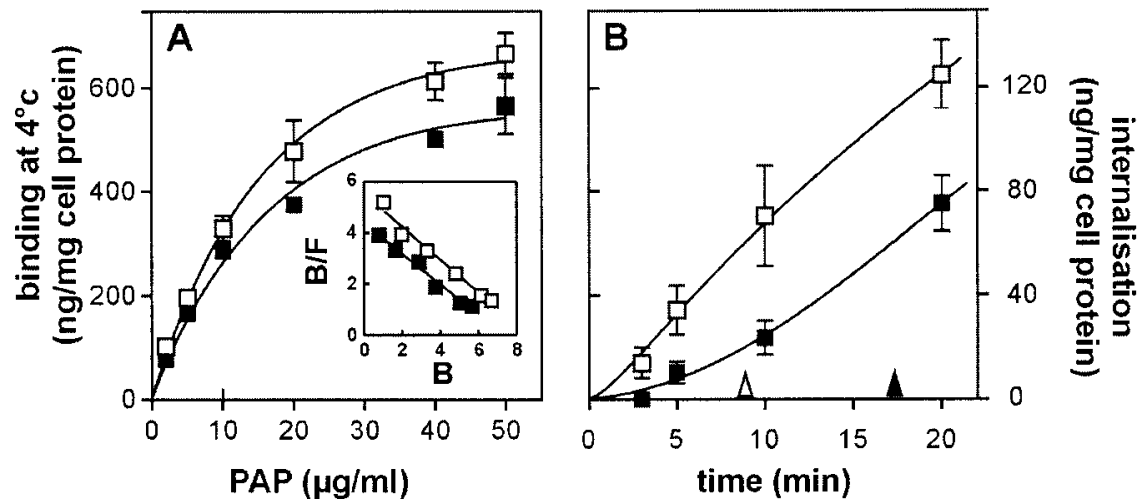

FIG. 4. Effect of azithromycin on PAP immune complex binding and internalization in J 774 macrophages. Cells were either left untreated (open squares) or pretreated with $100 \mathrm{mg} / \mathrm{L}$ azithromycin for $3 \mathrm{~h}$ (filled squares). (A) Specific binding of PAP immune complexes; control and treated cells were exposed to the indicated concentrations of PAP at $4^{\circ} \mathrm{C}$ for $2 \mathrm{~h}$ and then cell-associated peroxidase was assayed (nonspecific binding, measured with excess mouse IgG, was subtracted). Inset: Scatchard plot of the same data (bound values are in ng - mg cell protein ${ }^{-1} \times 10^{-2}$; bound/free ratios in $\mu \mathrm{l} \cdot \mathrm{mg}$ cell protein ${ }^{-1} \times 10^{-1}$ ). (B) Internalization of PAP immune complexes; cells were surface labeled with $20 \mu \mathrm{g} / \mathrm{ml} \mathrm{PAP}$ at $4^{\circ} \mathrm{C}$, washed, and reincubated at $37^{\circ} \mathrm{C}$ in tracer-free medium for the indicated times, after which peroxidase activity resisting surface displacement by excess mouse IgG was measured. Open and filled arrowheads on the horizontal axis refer to the interval for uptake to reach $60 \mathrm{ng} \cdot \mathrm{mg}$ cell protein ${ }^{-1}$ in control (open arrowhead) and azithromycin-treated cells (filled arrowhead). Experiments were reproduced twice with similar results.

value; Fig. $3 \mathrm{~A}$ inset). Intracellular sequestration of ${ }^{125}$ transferrin at $37^{\circ} \mathrm{C}$ was dramatically decreased in absolute terms (Fig. 3B), almost in proportion to the loss of surface receptor pool. Indeed, the internalization efficiency of surface-bound tracer was essentially unaffected (Fig. 3C), except for a systematic delay of 0.5-1 min. In subsequent experiments, we observed that the extent of disappearance of transferrin surface receptors and of the delay in the internalization of transferrin were both directly related to the extracellular concentration of azithromycin during the pretreatment period (data not shown).

When recycling was studied after a 3-min pulse (without surface acid stripping), Pronase-resistant values first showed a paradoxical increase in azithromycin-treated cells, indicating that more surface-bound tracer entered the intracellular pool than the amount concomitantly lost by recycling. Moreover, recycling was remarkably delayed by $\sim 10 \mathrm{~min}$, after which essentially all intracellular transferrin was released into the extracellular medium with a somewhat accelerated kinetics ( $\mathrm{t}_{1 / 2}$ of $\sim 12 \mathrm{~min}$ compared with $\sim 18 \mathrm{~min}$ in control cells), as if compensating for the delayed efflux.

Azithromycin Marginally Affects the Surface Pool of

Fc $\gamma$ Receptors but Markedly Delays I nternalization of PAP Immune Complexes in J 774 Cells

To address the effects of azithromycin on ligandinduced, receptor-mediated endocytosis into the degradation pathway, the dynamics of FC $\gamma$ receptors was examined by following the binding and internalization of mouse PAP complexes, assayed by their peroxidase activity. In contrast to transferrin receptors, the internalization of $\mathrm{FC} \gamma$ receptors depends on ligand binding, after which ligand/receptor complexes are delivered to lysosomes [48]. PAP binding at $4^{\circ} \mathrm{C}$ showed saturation (Fig. 4A), with a surface pool estimated at $850 \mathrm{ng} \cdot \mathrm{mg}$ cell protein ${ }^{-1}$, corresponding to $\sim 220,000$ ligand binding sites $\cdot$ cell $^{-1}$ with a single class of receptors exhibiting an apparent $K_{d}$ of $\sim 40 \mathrm{nM}$, based on Scatchard plot analysis and assuming a 1:1 ligand:receptor stoichiometry. These values are in agreement with a previous report [34].

It is clear that the number of receptors would be underestimated and their affinity overestimated if each PAP immune complex interacted with more than one Fc $\gamma$ receptor. Although PAP complexes consist primarily of two IgG molecules with their Fc ends pointed to opposite directions and of three peroxidase molecules in the center of the complex, and are therefore potentially divalent, the steric arrangement of $\mathrm{Fc}$ ends does not favor both of them binding to neighboring $\mathrm{Fc}$ receptor in the same plasma membrane. Accordingly, PAP immune complexes have been regarded by some investigators as a monovalent ligand [39, 49]. However, to the best of our knowledge, the effective receptor valency of PAP immune complexes with respect to $\mathrm{F} C \gamma$ receptor at the cell surface is not yet established.

The surface pool of $F c \gamma$ receptor was only marginally decreased upon azithromycin treatment (to $\sim 185,000$ sites $\cdot$ cell $^{-1}$ ), with no detectable change in affinity (Fig. $4 A$ inset). In untreated cells, internalization of PAP at 

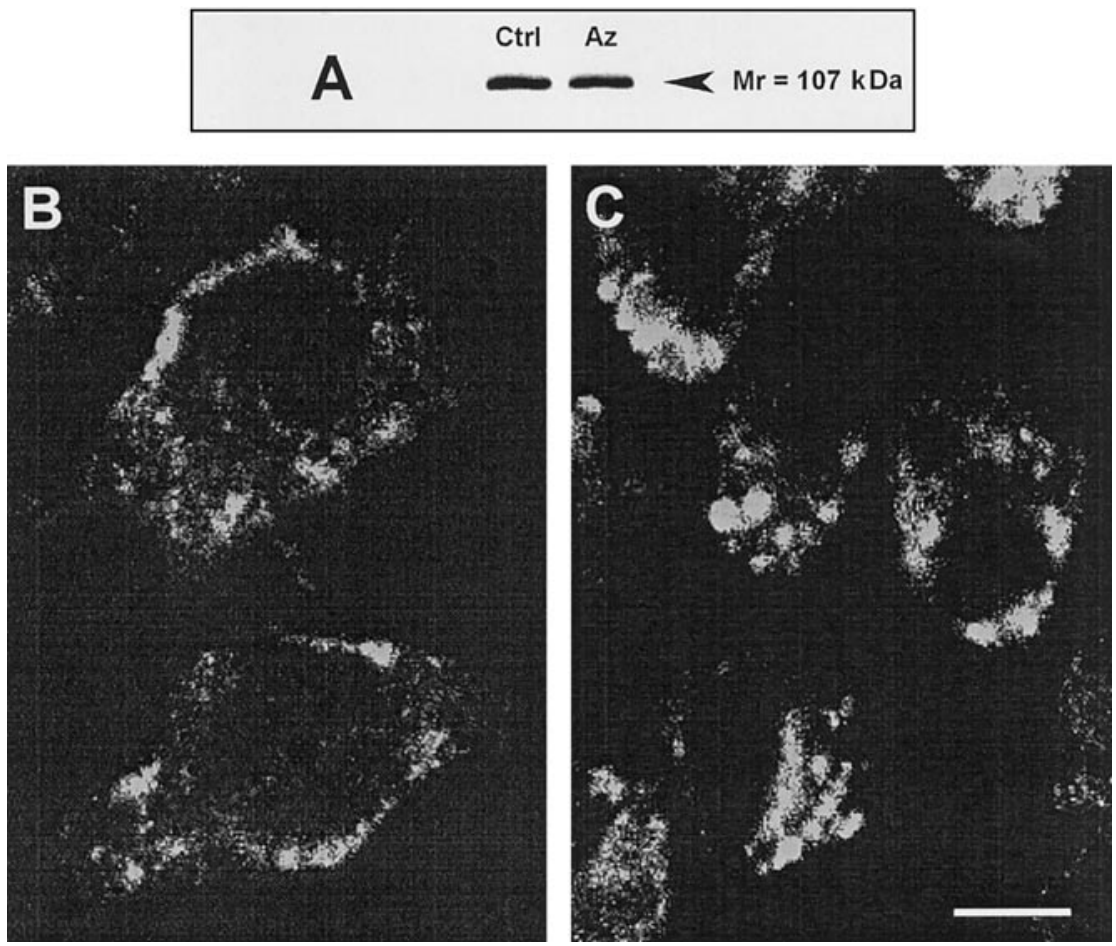

FIG. 5. Effects of azithromycin on total content and localization of transferrin receptors in J 774 cells. (A) Western blot of J 774 extracts prepared under reducing conditions (30 $\mu \mathrm{g}$ protein per lane); Ctrl, control cells (untreated); Az, cells pretreated with $100 \mathrm{mg} / \mathrm{L}$ azithromycin for $3 \mathrm{~h}$. (B and C) Immunofluorescence by confocal microscopy; cells were either left untreated (B) or treated by 100 mg/L azithromycin for $3 \mathrm{~h}(\mathrm{C})$, fixed, and permeabilized, after which transferrin receptor was localized by the same antibody as used for Western blotting. Experiments were reproduced three times $(A)$ or twice (B and $C$ ) with similar results.

$37^{\circ} \mathrm{C}$ proceeded linearly for about 45 min (see kinetics over the first 20 min in Fig. 4B) and then leveled off after $\sim 1 \mathrm{~h}$ (not shown). In azithromycin-treated cells, PAP internalization was clearly delayed by $\sim 10 \mathrm{~min}$, after which its rate of accumulation became comparable to that of control cells (Fig. 4B) and then reached essentially the same level after $1 \mathrm{~h}$ (not shown).

\section{Azithromycin Causes No Apparent Loss but a}

Redistribution of Transferrin Receptors,

While F c $\gamma$ Receptors Are Unaffected

In view of the major decrease in the transferrinreceptor surface pool upon azithromycin treatment, Western blotting and confocal microscopy were used to examine whether the drug would modify the size of the total cellular pool of receptors or induce its redistribution. By Western blotting, a major band at $M_{r} 107,000$ was clearly detected in both control and azithromycintreated cells (Fig. 5A), together with an additional minor band at $M_{r}$ 31,000 (not shown), as reported by other investigators [50]. Densitometric scanning showed no significant difference in the abundance of the transferrin receptor in treated cells compared with controls (94 $\pm 6 \% ; n=4 ; N S)$. The same antibodies were then used for transferrin-receptor immunolocal- ization by confocal microscopy (Figs. 5B and 5C). In control cells, staining was essentially associated with peripheral or perinuclear cytoplasmic dots, together with a faint labeling of the cell surface. This is consistent with the known distribution of the transferrin receptor, which prevalently occurs in endosomal structures involved in transferrin/receptor complex recycling and intracellular iron unloading, with a minor pool being exposed at the cell surface [38]. In azithromycin-treated cells, the intensity of immunolabeling and the size of these granular structures were apparently increased with a quasi-complete disappearance of the pericellular labeling, consistent with redistribution from a surface to an intracellular pool. In contrast, no detectable difference in the immunofluorescence pattern or intensity of $\mathrm{F} c \gamma$ receptors between control and azithromycin-treated cells could be evidenced (data not shown).

Azithromycin Causes an Intense Vacuolation of J 774

Macrophages; These Vacuoles Are Acidic and,

Once Formed, Are Inaccessible to Newly

Endocytosed HRP and PAP Complexes

Figure 6 shows the ultrastructural appearance of azithromycin-treated cells and the localization of HRP 

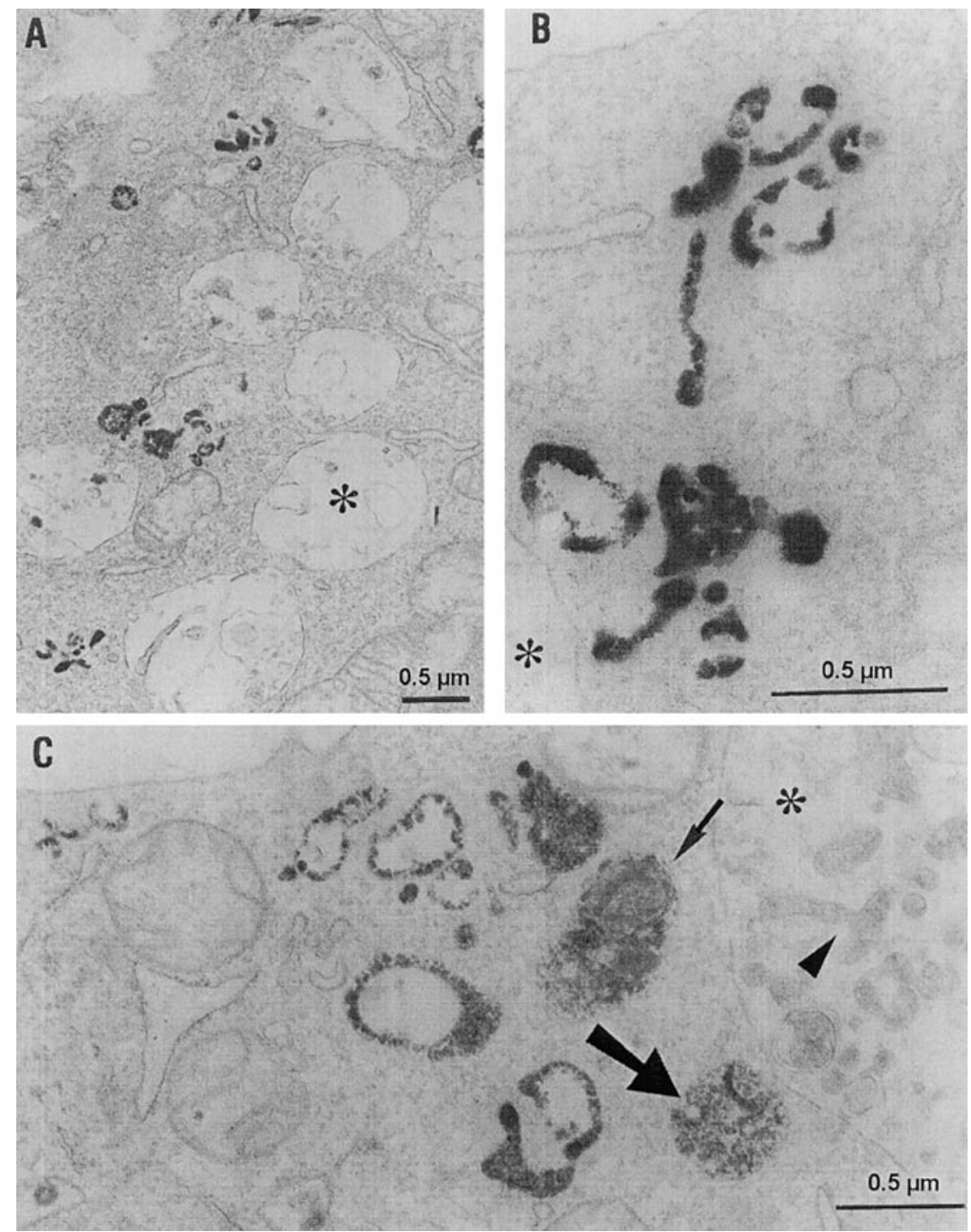

FIG. 6. Ultrastructural appearance and peroxidase cytochemistry of azithromycin-treated $\mathrm{J} 774$ macrophages. Cells were further challenged with HRP for 5 min (A, B) or $2 \mathrm{~h}$ (C). Notice the large number of vacuoles (marked by asterisks) displaying multiple luminal vesicles or branched tubular invaginations (arrowhead in C). These vacuoles are consistently devoid of peroxidase reaction product, even when in close vicinity to HRP-labeled structures, such as endosomes, undilated multivesicular bodies (thick arrow in C), and undilated residual bodies (small arrow in C). Notice the normal appearance of endoplasmic reticulum and mitochondria. Experiments were reproduced twice with similar results.

at $5 \mathrm{~min}(\mathrm{~A}, \mathrm{~B})$ and $2 \mathrm{~h}(\mathrm{C})$ after tracer addition, as revealed by cytochemical staining. The most striking observation was the formation of several-micrometerswide electron-lucent vesicles scattered throughout the cytoplasm, concomitant with the almost complete disappearance of typical lysosomes. The Golgi apparatus was moderately swollen; but no other ultrastructural alteration was noticed; in particular, mitochondria and the endoplasmic reticulum appeared normal. The large vacuoles induced by azithromycin contained multiple membrane-bound profiles, including branched tubular invaginations, and were consistently devoid of peroxidase-reaction product. Even after $2 \mathrm{~h}$ of incubation with HRP, this tracer remained essentially restricted to tubulospherical endosomes of normal appearance; the few multivesicular and residual bodies that resisted vacuolation were also labeled after this interval (see Fig. 6C). This was in sharp contrast with untreated cells, in which HRP was almost completely transferred from early endosomes to typical lysosomes (not shown), as is well known for macrophages [51] and fibroblasts [5, 33].

The nature of the large vacuoles induced by azithromycin was further examined using LysoTracker Green DND-26, a fluorophore which concentrates in acidic cellular compartments such as late endosomes and ly- 


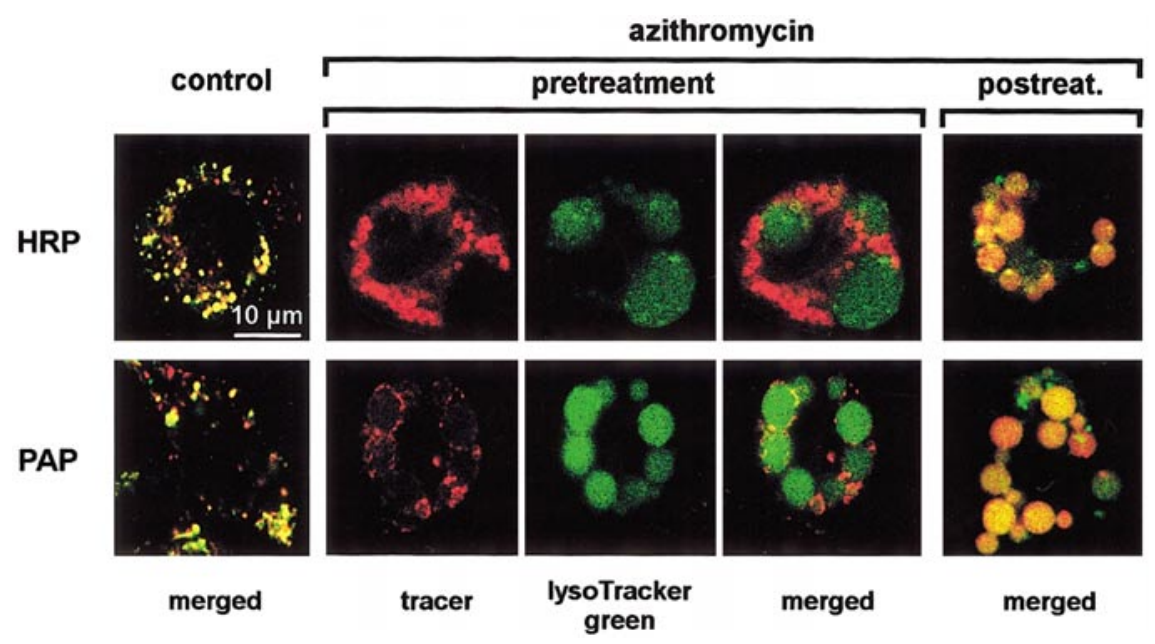

FIG. 7. Live cell imaging of control and treated J 774 macrophages. The fluid-phase endocytic tracer, HRP (rhodamine-labeled, upper row), and the receptor-mediated endocytic tracer, PAP (Alexa-Fluor-labeled, lower row), are seen in the red channel. The acidotropic marker, LysoTracker green, is seen in the green channel. Merged images combine signals of the red and green channels, which were recorded separately. Control: cells were incubated with the endocytic tracers for $1 \mathrm{~h}$, then exposed to LysoTracker green for 2 additional hours in the absence of endocytic tracers. Azithromycin pretreatment; cells were treated with $100 \mathrm{mg} / \mathrm{L}$ azithromycin for $3 \mathrm{~h}$, then incubated with the endocytic tracers for $1 \mathrm{~h}$ in the absence of azithromycin, and further exposed to LysoTracker green for 2 additional hours in the absence of endocytic tracers and of azithromycin. Azithromycin posttreatment: cells were first incubated with the endocytic tracers for $1 \mathrm{~h}$, chased in tracer-free medium overnight, and then treated with $100 \mathrm{mg} / \mathrm{L}$ azithromycin for $3 \mathrm{~h}$ in the presence of LysoTracker green. Experiments were reproduced three times with similar results.

sosomes. When control cells were allowed to endocytose rhodamine-labeled HRP or Alexa-Fluor-labeled PAP complexes for $1 \mathrm{~h}$ and then exposed to LysoTracker green for $2 \mathrm{~h}$ in HRP- or PAP-free medium, LysoTracker green consistently stained small-sized vesicles scattered through the cytoplasm. Most of them also contained HRP or PAP complexes, resulting in a yellow color in the merged image (Fig. 7, left). In azithromycin-treated cells, LysoTracker green was prominently concentrated in a few large vacuoles, which could exceed $10 \mu \mathrm{m}$ in diameter, and the intensity of LysoTracker green signal appeared somewhat inversely related with vacuolar size. Biochemical assays revealed that accumulation of LysoTracker $(1.5 \mu \mathrm{M})$ was decreased by about half upon azithromycin treatment $\left(218 \pm 18 \mathrm{pmol} \cdot \mathrm{mg}\right.$ cell protein ${ }^{-1}$ vs $410 \pm 19$ pmol $\cdot \mathrm{mg}$ cell protein ${ }^{-1}$ in untreated cells; $\mathrm{n}=3 ; \mathrm{P}<$ 0.01). LysoTracker-labeled vacuoles disappeared after overnight incubation in drug-free medium (not shown), at which time essentially all cell-associated drug had been released (see Fig. 2B).

We further compared these properties of azithromycin with those of chloroquine, since the acidotropic effects of chloroquine have been most extensively studied $[52,53]$. At $132 \mu \mathrm{M}$ chloroquine, a concentration known to decrease by half the acidification of endocytic organelles [53], (i) this drug was concentrated in J 774 cells $\sim 100$-fold, like azithromycin; (ii) chloroquine also induced the formation of vacuoles that showed homogeneous LysoTracker labelling, albeit vacuolation was less extensive than with azithromycin (vacuoles did not exceed 2-3 $\mu \mathrm{m}$ in diameter); and (iii) in contrast with azithromycin, chloroquine did not decrease the net accumulation of $1.5 \mu \mathrm{M}$ LysoTracker (404 $\pm 34 \mathrm{pmol} / \mathrm{mg}$ cell protein vs $410 \pm 19 \mathrm{pmol} / \mathrm{mg}$ cell protein in untreated cells; NS).

In good agreement with ultrastructural cytochemistry, azithromycin-treated cells showed complete segregation between rhodamine-HRP-labeled small vesicles and the large LysoTracker-labeled vacuoles (Fig. 7, azithromycin pretreatment, upper row). Alexa PAPlabeled structures and LysoTracker-labeled vacuoles were similarly segregated. The small fluorescent vesicles containing HRP or PAP were often seen immediately around large vacuoles, as if preparing for docking (Fig. 7, azithromycin pretreatment, lower row). U pon time-lapse imaging, however, these vesicles were seen to move quickly along large vacuoles without discernible fusion and content mixing (data not shown).

Whereas the large, LysoTracker-positive vacuoles induced by azithromycin were thus essentially inaccessible to HRP or PAP when these tracers were added to cells after the vacuoles had been formed, the converse was not true. Indeed, both HRP and PAP, having ended up in late endosomes/lysosomes after $1 \mathrm{~h}$ of uptake and an overnight chase (both in the absence of azithromycin), clearly localized within the vacuoles that developed upon subsequent exposure to the drug (Fig. 7, right). 

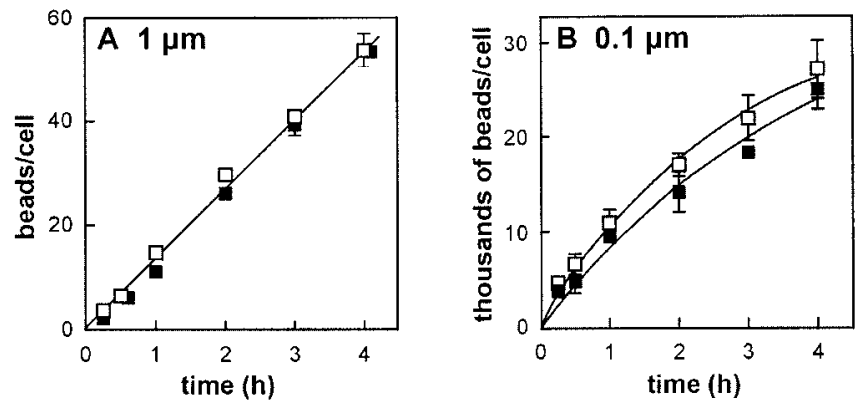

FIG. 8. Phagocytosis of Texas red-labeled latex beads by J 774 mouse macrophages. Cells were either left untreated (open squares) or treated by $100 \mathrm{mg} / \mathrm{L}$ azithromycin for $3 \mathrm{~h}$ (filled squares) prior to challenge with latex beads for the indicated times. (A) Large beads ( 270 particles $\left.\cdot \mathrm{nl}^{-1}\right)$; (B) small beads $\left(230,000\right.$ particles $\left.\cdot \mathrm{nl}^{-1}\right)$. Statistical analysis showed no significant difference between control and azithromycin-pretreated cells. Experiments were reproduced three times with similar results.

Azithromycin Affects neither Phagocytosis of Latex Beads nor Their Access to Azithromycin-Induced Vacuoles

The effect of azithromycin on phagocytosis was investigated by studying the accumulation of carboxy- late-modified polystyrene latex beads covalently coupled with Texas red of large ( $1 \mu \mathrm{m} ; 270$ particles $\cdot \mathrm{nl}^{-1}$ ) and small size $\left(0.1 \mu \mathrm{m} ; 230,000\right.$ particles $\cdot \mathrm{nl}^{-1}$, for equal sensitivity of detection). It was verified that uptake of $1-\mu \mathrm{m}$ latex beads was identical whether they were precoated or not with I gG or serum and whether phagocytosis took place in the presence of untreated serum, of heat-decomplemented serum, or in the absence of serum. Figure 8 shows that the rate of accumulation of the large beads was constant for at least $4 \mathrm{~h}$ (clearance of $\sim 3 \mu \mathrm{l} \cdot \mathrm{min}^{-1} \cdot \mathrm{mg}$ cell protein ${ }^{-1}$ ). Accumulation of the small beads was comparable, albeit with a slightly faster initial clearance ( $\sim 6$ $\mu \mathrm{l} \cdot \mathrm{min}^{-1} \cdot \mathrm{mg}$ cell protein ${ }^{-1}$ at $15 \mathrm{~min}$ ), followed by a slower clearance $\left(2 \mu \mathrm{l} \cdot \mathrm{min}^{-1} \cdot \mathrm{mg}\right.$ cell protein ${ }^{-1}$ at $\left.4 \mathrm{~h}\right)$. As shown in Fig. 8, pretreatment of the cells with azithromycin did not alter phagocytosis of large beads at any time and only marginally that of the small beads. After $2 \mathrm{~h}$ of uptake, there was no sign of saturation for the large beads up to 400 beads $\cdot \mathrm{nl}^{-1}$, but a tendency toward saturation for the small beads $(\sim 40 \%$ deviation from linearity at 450,000 beads $\left.\cdot \mathrm{nl}^{-1}\right)$. This could be easily explained by comparing the membrane area of the plasma membrane of J 774 macrophages
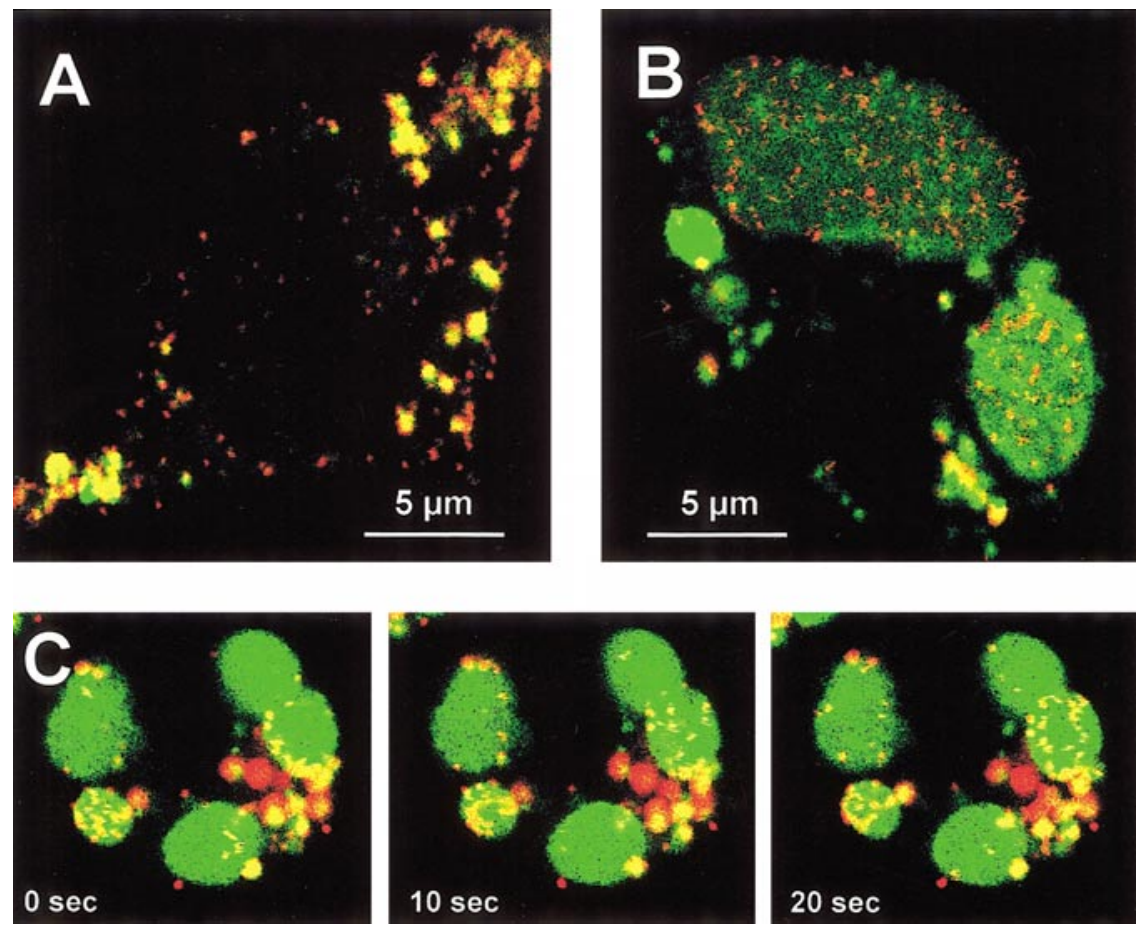

FIG. 9. Confocal life cell imaging of latex bead phagocytosis in J 774 macrophages combined with vital staining of lysosomes (merged images). (A) Untreated cells were incubated with $0.1-\mu \mathrm{m}$ Texas red-labeled latex beads for $1 \mathrm{~h}$ and then reincubated without beads but with LysoTracker green for $2 \mathrm{~h}$. (B) Cells were pretreated with $100 \mathrm{mg} / \mathrm{L}$ azithromycin for $3 \mathrm{~h}$, then similarly incubated with latex beads for $1 \mathrm{~h}$ in the absence of azithromycin, and finally reincubated with LysoTracker green for $2 \mathrm{~h}$ in the absence of both latex beads and azithromycin. (C) Same field of cells treated as in B and photographed at 10-s intervals. Several beads present in the large vacuoles, thus appearing yellow, show different locations in the three images, demonstrating a rapid intravesicular movement. Experiments were reproduced twice with similar results. 
$\left(\sim 1200 \mu \mathrm{m}^{2}\right)$ [54] with the estimated internalized membrane required to form the deduced number of $0.1-\mu \mathrm{m}$ phagosomes $\left(\sim 630 \mu \mathrm{m}^{2}\right)$ compared with the $1-\mu \mathrm{m}$ phagosomes $\left(\sim 125 \mu \mathrm{m}^{2}\right)$. Again, no significant effect of a pretreatment with azithromycin was noted (data not shown).

In the confocal microscope, the many small vesicles labeled in control cells by LysoTracker green were largely accessible to Texas red-labeled $0.1-\mu \mathrm{m}$ latex beads (Fig. 9A). Azithromycin-pretreated cells also showed a clear colocalization of both tracers, and Texas red-labeled particles were detected as multiple dots within the large LysoTracker-containing vacuoles (Fig. 9B). Occurrence of freely moving latex beads within these structures was further demonstrated by timelapse imaging (Fig. 9C).

\section{DISCUSSION}

This report discloses several striking findings on the inhibitory effects of azithromycin on endocytosis and shows that this drug can exert distinct effects on its main pathways.

First, this study extends to the $\mathbf{7 7 4}$ mouse macrophage cell line preliminary evidence obtained by our laboratories on the inhibition by azithromycin of fluidphase endocytosis in primary cultures of rat fetal fibroblasts [33]. Based on an extensive set of biochemical data obtained with two unrelated tracers combined with morphological data by live-cell imaging and ultrastructural cytochemistry, the present observations demonstrate that azithromycin is an inhibitor of fluidphase endocytosis by selectively impairing the uptake of solutes in a dose-dependent manner. Although azithromycin further prevents their accessibility to lysosomes, it does not accelerate tracer regurgitation, in contrast to other perturbations or drugs that concomitantly block transfer to lysosomes and promote regurgitation [23].

Second, the two crucial steps accounting for the selectivity of receptor-mediated endocytosis, namely the sequestration of ligand/receptor complexes into endocytic pits (as most obvious for PAP immune complexes) and the accessibility of transferrin to the recycling route, appear particularly vulnerable to azithromycin. In treated cells, the disproportion between the major delay in the accessibility of internalized transferrin to the recycling pathway, as opposed to the minor delay in receptor-mediated entry, easily accounts for the major decrease in the surface pool of transferrin receptors, without detectable loss of the total cell complement of receptors. In turn, the major decrease in the surface pool of transferrin receptors leads to a proportional inhibition of receptor-mediated endocytosis in absolute terms, which contrasts with an almost identical efficiency of internalization of receptor-bound ligands, ex- cept for the slight delay in primary sequestration. In retrospect, such a delay could be recognized for another weak base, methylamine, in the historical report of receptor-mediated endocytosis of $\alpha_{2}$-macroglobulintrypsin/receptor complexes in macrophages [55].

This delay suggests interference with lateral mobility (discussed below) and/or availability of a rate-limiting factor for coat recruitment [56], e.g., a Rab protein acting as a timer [57]. Sensitivity to this delaying effect of azithromycin was higher for PAP immune complexes, possibly due to (i) the larger size of ligand/receptor complexes, (ii) the potential multivalency of the ligand, and/or (iii) different requirements for a ligand-induced process. Conversely, no delay was observed for receptormediated endocytosis of transferrin in rat fetal fibroblasts, possibly because internalization of receptor-bound ligands proceeds at an approximately fourfold slower rate than in $\mathrm{j} 774$ macrophages [8\% $\cdot \mathrm{min}^{-1}$ in fibroblasts [33] vs $>30 \% \cdot \min ^{-1}$ (this report)].

Third, azithromycin clearly leaves the phagocytosis pathway completely unaffected, which is an interesting feature for an antibiotic in a clinical perspective, since phagocytosis of bacteria is an important component of a successful host defense against infection. This is consistent with other reports indicating that azithromycin does not impair the uptake of opsonized Staphylococcus aureus or zymosan $[58,59]$ and underlines that endocytosis and phagocytosis are distinct processes, governed, at least partly, by distinct machineries.

Fourth, azithromycin most conspicuously causes extensive vacuolation of the late, actively acidified endocytic compartments. That these vacuoles originate from late endosomes/lysosomes is strongly suggested by their labeling with LysoTracker green, their multivesicular and tubular content, and the concomitant disappearance of typical lysosomes and conversely, by vacuole disappearance and lysosome reappearance upon loss of cell-associated drug in chase experiments. We may reasonably assume that this vacuolation is caused by the massive accumulation of azithromycin in these acidic vacuoles and the ensuing increase in osmotic pressure. Azithromycin storage in lysosomes has been directly demonstrated in J 774 macrophages exposed to lower concentrations of azithromycin (10 $\mathrm{mg} / \mathrm{L}$ ) using cell fractionation techniques [60]. This accumulation is not surprising since the drug is an amphiphilic molecule bearing two basic functions with appropriately weak $\mathrm{pK}_{\mathrm{a}}$ values [8.1 for the endocyclic tertiary amine and 8.8 for the tertiary amine carried by one of the two sugar moieties (desosamine)]. It is therefore susceptible, like chloroquine [45] and many other cationic amphiphiles, to accumulating in lysosomes and other acidic membrane-bound compartments by proton trapping [52]. As anticipated, accumulation of azithromycin was impaired by monensin, a drug known to collapse transmembrane $\mathrm{pH}$ gradients [61]. 
Three lines of evidence suggest that azithromycin causes a more severe impairment of acidification than chloroquine: the stronger vacuolating effect of azithromycin compared with the same concentration of chloroquine, the lower accumulation of LysoTracker green in a biochemical assay, and the fainter green fluorescence by confocal microscopy. With respect to chloroquine, the net accumulation of LysoTracker identical to that in untreated cells suggests a strictly inverse relationship between vacuolation and impaired acidification.

Like azithromycin, chloroquine and primaquine (a close congener of chloroquine) inhibit fluid-phase endocytosis, cause the intracellular sequestration of transferrin receptor $[62,63]$, and severely impair the accessibility of fluid-phase tracers to lysosomes [19]. That all three drugs are dicationic amphiphiles and have similar effects suggests a common mechanism: interference with the acidification of late endosomes and Iysosomes (resulting in a defective recruitment the COP machinery required for the budding of endocytic carrier vesicles [64]) or intense vacuolation (so that swollen late endosomes/lysosomes would become unable to fuse with incoming endosomes). Perturbation of endocytosis by vacuolation has already been observed with other basic drugs such as nicotine or procaine amide [65] but was not fully documented in terms of specificity toward one or several pathways of endocytosis. Biogenesis of phagolysosomes proceeds through sequential interactions between components of the endocytic apparatus [66]. These involve exchanges between newly formed phagosomes and early endosomes and the gradual acquisition of lysosome-like properties by repeated fusion with Iysosomes as well as trans-Golgi network-derived vesicles [36]. The lack of inhibition by azithromycin on the accessibility of latex beads to lysosomes indicates that forces causing fusion of phagosomes, but not of endosomes, can overcome the increased membrane tension due to vacuolation of late endosomes/lysosomes.

This does not explain, however, some discrepancies between azithromycin and chloroquine [45] or sucrose [67], which also cause extensive vacuolation of the late endocytic apparatus. In particular, azithromycin does not inhibit phagocytosis nor alter the accessibility of phagocytosed latex beads into lysosomes, in contrast with chloroquine $[68,69]$, but similar to $\varepsilon$-COP-defective cells [70]. Moreover, interference with acidification and/or vacuolation do not directly account for two distinct properties of azithromycin that, it should be noted, could be evidenced even several hours after drug withdrawal. First, azithromycin delayed sequestration in clathrin-coated pits of receptor-bound ligands, as best evidenced for PAP/F $\gamma$ receptor complexes $(\sim 10$ min), but did not appreciably affect the subsequent rate of endocytosis per se. Second, azithromycin causes a major delay of transferrin-receptor recycling ( $\sim 10$ min) without impairing the subsequent rate of efflux, which contrasts with the absence of reported delay but prolonged half-life of efflux of transferrin receptors in cells treated with monensin and bafilomycin A1 [7, 23, 24], two drugs known to markedly impair acidification of endosomes and lysosomes [71, 72].

Thus, to account for the delay in endocytic sequestration and recycling, more specific mechanims such as interference with coat components should be envisaged. One candidate might be dynamin, regarded as a "pinchase" [73], but it is unlikely that azithromycin acts by interfering with its interaction with the plasma membrane, since dominant-negative dynamin causes a stable inhibition in the rate of receptor-mediated endocytosis and phagocytosis, but is rapidly compensated for with respect to fluid-phase endocytosis [11-13]. A second candidate could be Rab5, a rate-limiting catalyst of endocytosis. Dominant-negative Rab5 slows down fluid-phase endocytosis, but it inhibits to a comparable extent the rate of receptor-mediated endocytosis of transferrin [17]. Conversely, dominant-positive Rab5 accelerates phagocytosis [74, 75]. A third candidate is the COP complex. Some features of azithromycin-treated cells are indeed reminiscent of $\varepsilon$-COP inactivation in $\mathrm{CHO}$ cells, which (i) selectively inhibits fluid-phase endocytosis when measured after long intervals, (ii) may inhibit receptor-mediated endocytosis [76], (iii) does not inhibit phagocytosis, and (iv) blocks transfer of a pinocytosed tracer to lysosomes, but not maturation of phagosomes [64, 70, 77]. However, $\varepsilon$-COP inactivation does not delay receptor-mediated endocytosis [76] (but see also [77]). Alternatively, decreased lateral diffusion [78] or impaired membrane partitioning [79] could explain the delay of ligand-induced sequestration of $\mathrm{FC} \gamma$ receptor into clathrincoated vesicles and of incorporation of transferrin-receptor into recycling vesicles.

It is now well accepted that pinocytosis involves both clathrin-dependent and clathrin-independent pathways [80-82]. In this context, azithromycin was found not to affect the steady-state efficiency of receptormediated endocytosis (i.e., the budding of clathrincoated pits into clathrin-coated vesicles), but to decrease by about half the rate of fluid-phase endocytosis. Since the latter reflects the sum of both clathrin-associated and clathrin-independent bulk-flow endocytosis, and since the rate of receptor-mediated endocytosis per se is not affected, one is led to conclude that azithromycin selectively inhibits clathrin-independent endocytosis. Phagosomes and clathrin-coated vesicles are clearly surrounded by a cytoplasmic coat that imposes a local constraint on membrane fluidity. For example, this coat protects clathrin-coated structures against "corrugation" by the cholesterol-complexing agent, filipin [83]. In contrast, no such coat has been reported so 
far for clathrin-independent endocytic vesicles. Bulkflow endocytosis may be affected not only by local lipid asymmetry across the bilayer, but also by physical forces such as tension and fluidity $[84,85]$. That clathrin-independent endocytosis is particularly sensitive to such biophysical parameters is supported by its selective inhibition by low concentrations of PEG-cholesterol, whereas impairment of incurvation of clathrincoated pits requires higher concentrations [86, 87]. In this respect, interaction of azithromycin with membrane phospholipids is supported by direct in vitro evidence based on equilibrium dialysis with liposomes [88].

Whereas it is clear that rigorous studies with pharmacological agents require several controls, it is suggested that azithromycin, or related agents, could be useful for kinetics studies addressing the contribution of clathrin-independent endocytosis [82], sorting steps in the recycling pathway [89], fusogenicity of phagosomes [90], and possibly cell signaling [91], as well as the roles and functions of the various endocytic pathways in pathology and pharmacotoxicology.

The skillful technical assistance of N. Aguilera, F. Andries-Renoird, M.-C. Cambier, T. Lac, M. Leruth, and F. Pyrrhon-N'Kuli as well as the excellent secretarial assistance of $Y$. Marchand is gratefully acknowledged. Ph. de Diesbach collaborated in some experiments. D.T. was a Research Fellow, F.V.B. a Research Associate, and M.P.M. a Senior Research Associate of the Belgian Fonds National de la Recherche Scientifique (FNRS). This work was supported by grants from the Belgian FNRS (1.5206.99 to P.T.) and the Belgian Fonds de la Recherche Scientifique Médicale (FRSM 3.4.549.00 to P.T., 3.4.546.02 to M.P.M. and 3.4621.01 to P.C.), the Actions de Recherches Concertées of the Direction Générale de la Recherche Scientifique-Communauté Française de Belgique (Contract 94/99172 to P.T., M.P.M., and P.C. and 99/04-236 to P.C.), and the Interuniversity Attraction Poles (to P.C.).

\section{REFERENCES}

1. Silverstein, S. C., Steinman, R. M., and Cohn, Z. A. (1977). Endocytosis. Annu. Rev. Biochem. 46, 669-722.

2. Mukherjee, S., Ghosh, R. N., and Maxfield, F. R. (1977). Endocytosis. Physiol Rev. 77, 759-803.

3. Marsh, M. (2001). "Endocytosis," Oxford Univ. Press, Oxford, UK.

4. Mellman, I. (1996). Endocytosis and molecular sorting. Annu. Rev. Cell Dev. Biol. 12, 575- 625.

5. Cupers, P., Veithen, A., Kiss, A., Baudhuin, P., and Courtoy, P. J. (1994). Clathrin polymerization is not required for bulkphase endocytosis in rat fetal fibroblasts. J. Cell. Biol. 127, 725-735.

6. Berthiaume, E. P., Medina, C., and Swanson, J. A. (1995). Molecular size-fractionation during endocytosis in macrophages. J . Cell. Biol. 129, 989-998.

7. van Weert, A. W., Dunn, K. W., Gueze, H. J ., Maxfield, F. R., and Stoorvogel, W. (1995). Transport from late endosomes to lysosomes, but not sorting of integral membrane proteins in endosomes, depends on the vacuolar proton pump. J . Cell. Biol. 130, 821-834.

8. Hao, M., and Maxfield, F. R. (2000). Characterization of rapid membrane internalization and recycling. J. Biol. Chem. 275, 15279-15286.
9. Robbins, A. R., Peng, S. S., and Marshall, J . L. (1983). Mutant Chinese hamster ovary cells pleiotropically defective in receptor-mediated endocytosis. J . Cell. Biol. 96, 1064-1071.

10. Guo, Q., Vasile, E., and Krieger, M. (1994). Disruptions in Gol gi structure and membrane traffic in a conditional lethal mammalian cell mutant are corrected by epsilon-COP. J . Cell. Biol. 125, 1213-1224.

11. Damke, H., Baba, T., Warnock, D. E., and Schmid, S. L. (1994). Induction of mutant dynamin specifically blocks endocytic coated vesicle formation. J . Cell. Biol. 127, 915-934.

12. Damke, H., Baba, T., van der Bliek, A. M., and Schmid, S. L. (1995). Clathrin-independent pinocytosis is induced in cells overexpressing a temperature-sensitive mutant of dynamin. J . Cell. Biol. 131, 69-80.

13. Gold, E. S., Underhill, D. M., Morrissette, N. S., Guo, J ., McNiven, M. A., and Aderem, A. (1999). Dynamin 2 is required for phagocytosis in macrophages. J . Exp. Med. 190, 1849-1856.

14. Nicoziani, P., Vilhardt, F., Llorente, A., Hilout, L., Courtoy, P. J ., Sandvig, K., and van Deurs, B. (2000). Role for dynamin in late endosome dynamics and trafficking of the cation-independent mannose 6-phosphate receptor. Mol. Biol. Cell 11, 481- 495.

15. van Dam, E. M., and Stoorvogel, W. (2002). Dynamin-dependent transferrin receptor recycling by endosome-derived clathrin-coated vesicles. Mol. Biol. Cell. 13, 169-182.

16. Damke, H., Binns, D. D., Ueda, H., Schmid, S. L., and Baba, T. (2001). Dynamin GTPase domain mutants block endocytic vesicle formation at morphologically distinct stages. Mol. Biol. Cell. 12, 2578-2589.

17. Bucci, C., Parton, R. G., Mather, I. H., Stunnenberg, H., Simons, K., H oflack, B., and Zerial, M. (1992). The small GTPase rab5 functions as a regulatory factor in the early endocytic pathway. Cell 70, 715-728.

18. Hedin, U., and Thyberg, J . (1985). Receptor-mediated endocytosis of immunoglobulin-coated colloidal gold particles in cultured mouse peritoneal macrophages. Chloroquine and monensin inhibit transfer of the ligand from endocytic vesicles to lysosomes. Eur. J . Cell. Biol. 39, 130-135.

19. Stenseth, K., and Thyberg, J . (1989). Monensin and chloroquine inhibit transfer to lysosomes of endocytosed macromolecules in cultured mouse peritoneal macrophages. Eur. J . Cell. Biol. 49, 326-333.

20. Gruenberg, J ., Griffiths, G., and Howell, K. E. (1989). Characterization of the early endosome and putative endocytic carrier vesicles in vivo and with an assay of vesicle fusion in vitro. J. Cell. Biol. 108, 1301-1316.

21. Clague, M. J ., Urbe, S., Aniento, F., and Gruenberg, J. (1994). Vacuolar ATPase activity is required for endosomal carrier vesicle formation. J . Biol. Chem. 269, 21-24.

22. van Deurs, B., Holm, P. K., and Sandvig, K. (1996). Inhibition of the vacuolar $\mathrm{H}(+)$-ATPase with bafilomycin reduces delivery of internalized molecules from mature multivesicular endosomes to lysosomes in HEp-2 cells. Eur. J . Cell. Biol. 69, 343-350.

23. Cupers, P., Veithen, A., Hoekstra, D., Baudhuin, P., and Courtoy, P. J . (1997). Three unrelated perturbations similarly uncouple fluid, bulk-membrane, and receptor endosomal flow in rat fetal fibroblasts. Biochem. Biophys. Res. Commun. 236, 661- 664.

24. Presley, J. F., Mayor, S., McGraw, T. E., Dunn, K. W., and Maxfield, F. R. (1997). Bafilomycin A1 treatment retards transferrin receptor recycling more than bulk membrane recycling. J. Biol. Chem. 272, 13929-13936.

25. Giurgea-Marion, L., Toubeau, G., Laurent, G., Heuson-Stiennon, J. A., and Tulkens, P. M. (1986). I mpairment of lysosomepinocytic vesicle fusion in rat kidney proximal tubules after 
treatment with gentamicin at low doses. Toxicol. Appl. Pharmacol. 86, 271-285.

26. Reasor, M. J ., and Kacew, S. (2001). Drug-induced phospholipidosis: Are there functional consequences? Exp. Biol. Med. (Maywood) 226, 825- 830.

27. Peyron, P., Bordier, C., N'Diaye, E. N., and Maridonneau-Parini, I. (2000). Nonopsonic phagocytosis of Mycobacterium kansasii by human neutrophils depends on cholesterol and is mediated by CR3 associated with glycosylphosphatidylinositolanchored proteins. J . Immunol. 165, 5186-5191.

28. Rodal, S. K., Skretting, G., Garred, O., Vilhardt, F., van Deurs, B., and Sandvig, K. (1999). Extraction of cholesterol with methyl-beta-cycl odextrin perturbs formation of clathrin-coated endocytic vesicles. Mol. Biol. Cell. 10, 961-974.

29. Subtil, A., Gaidarov, I., Kobylarz, K., Lampson, M. A., Keen, J. H., and McGraw, T. E. (1999). Acute cholesterol depletion inhibits clathrin-coated pit budding. Proc. Natl. Acad. Sci. USA 96, 6775- 6780 .

30. Thyberg, J ., and Nilsson, J . (1982). Effects of nicotine on endocytosis and intracellular degradation of horseradish peroxidase in cultivated mouse peritoneal macrophages. Acta Pathol. Microbiol. Immunol. Scand. [A] 90, 305-310.

31. Djokic, S., Kobrehel, G., and Lazarevski, G. (1987). Erythromycin series. XII. Antibacterial in vitro evaluation of 10-dihydro10-deoxo-11-azaerythromycin A: Synthesis and structure-activity relationship of its acyl derivatives. J . Antibiot. (Tokyo) 40, 1006-1015.

32. Bright, G. M., Nagel, A. A., Bordner, J ., Desai, K. A., Dibrino, J . N., Nowakowska, J ., Vincent, L., Watrous, R. M., Sciavolino, F. C., English, A. R., Retsema, J . A., Anderson, M. R., Brennan, L. A., Borovoy, R. J ., Cimochowski, C. R., Faiella, J . A., Girard, D., Herbert, C., Manousos, M., and Mason, R. (1988). Synthesis, in vitro and in vivo activity of novel 9-deoxo-9a-AZA-9a-homoerythromycin A derivatives: A new class of macrolide antibiotics, the azalides. J . Antibiot. (Tokyo) 41, 1029-1047.

33. Tyteca, D., Van Der Smissen, P., Van Bambeke, F., Leys, K., Tulkens, P. M., Courtoy, P. J ., and Mingeot-Leclercq, M. P. (2001). Azithromycin, a lysosomotropic antibiotic, impairs fluidphase pinocytosis in cultured fibroblasts. Eur. J . Cell. Biol. 80, 466- 478.

34. Mellman, I., and Plutner, H. (1984). Internalization and degradation of macrophage $\mathrm{F}$ c receptors bound to polyvalent immune complexes. J . Cell. Biol. 98, 1170-1177.

35. Swanson, J., Burke, E., and Silverstein, S. C. (1987). Tubular Iysosomes accompany stimulated pinocytosis in macrophages. J. Cell. Biol. 104, 1217-1222.

36. Pitt, A., Mayorga, L. S., Schwartz, A. L., and Stahl, P. D. (1992). Transport of phagosomal components to an endosomal compartment. J . Biol. Chem. 267, 126-132.

37. Steinman, R. M., and Cohn, Z. A. (1972). The interaction of particulate horseradish peroxidase (HRP)-anti HRP immune complexes with mouse peritoneal macrophages in vitro. J . Cell. Biol. 55, 616-634.

38. Rothenberger, S., Iacopetta, B. J ., and Kuhn, L. C. (1987). Endocytosis of the transferrin receptor requires the cytoplasmic domain but not its phosphorylation site. Cell 49, 423- 431.

39. Kiss, A. L., and Rohlich, P. (1984). Receptor-mediated pinocytosis of IgG and immune complex in rat peritoneal macrophages: An electron microscopic study. Eur. J. Cell. Biol. 34, 88-95.

40. Lovdal, T., Andersen, E., Brech, A., and Berg, T. (2000). Fc receptor mediated endocytosis of small soluble immunoglobulin $\mathrm{G}$ immune complexes in Kupffer and endothelial cells from rat liver. J . Cell. Sci. 113, 3255-3266.
41. Schroeder, F., and Kier, A. B. (1983). Lipid composition alters phagocytosis of fluorescent latex beads. J . Immunol. Methods 57, 363-371.

42. Snyderman, R., Pike, M. C., Fischer, D. G., and Koren, H. S. (1977). Biologic and biochemical activities of continuous macrophage cell lines P388D1 and J 774.1. J . Immunol. 119, 20602066.

43. Kienhuis, C. B., Heuvel, J. J., Ross, H. A., Swinkels, L. M., Foekens, J . A., and Benraad, T. J . (1991). Six methods for direct radioiodination of mouse epidermal growth factor compared: Effect of nonequivalence in binding behavior between labeled and unlabeled ligand. Clin. Chem. 37, 1749-1755.

44. Montenez, J. P., Van Bambeke, F., Piret, J., Brasseur, R., Tulkens, P. M., and Mingeot-Leclercq, M. P. (1999). Interactions of macrolide antibiotics (erythromycin A, roxithromycin, erythromycylamine [Dirithromycin], and azithromycin) with phospholipids: Computer-aided conformational analysis and studies on acellular and cell culture models. Toxicol. Appl. Pharmacol. 156, 129-140.

45. Wibo, M., and Poole, B. (1974). Protein degradation in cultured cells. II. The uptake of chloroquine by rat fibroblasts and the inhibition of cellular protein degradation and cathepsin B1. J . Cell. Biol. 63, 430-440.

46. Schmid, S. L., and Smythe, E. (1991). Stage-specific assays for coated pit formation and coated vesicle budding in vitro. J . Cell. Biol. 114, 869-880.

47. Wiley, H. S., and Cunningham, D. D. (1982). The endocytotic rate constant. A cellular parameter for quantitating receptormediated endocytosis. J . Biol. Chem. 257, 4222- 4229.

48. Ukkonen, P., Lewis, V., Marsh, M., Helenius, A., and Mellman, I. (1986). Transport of macrophage F c receptors and F c receptor-bound ligands to lysosomes. J . Exp. Med. 163, 952-971.

49. Kiss, A. L., and Rohlich, P. (1987). Reappearance of immune complex binding sites on macrophages after internalization and its inhibition by monensin. Eur. J . Cell. Biol. 43, 322-328.

50. Van Agthoven, A., Goridis, C., Naquet, P., Pierres, A., and Pierres, M. (1984). Structural characteristics of the mouse transferrin receptor. Eur. J . Biochem. 140, 433- 440.

51. Steinman, R. M., Brodie, S. E., and Cohn, Z. A. (1976). Membrane flow during pinocytosis. A stereologic analysis. J. Cell. Biol. 68, 665- 687.

52. de Duve, C., de Barsy, T., Poole, B., Trouet, A., Tulkens, P., and Van Hoof, F. (1974). Lysosomotropic agents. Biochem. Pharmacol. 23, 2495-2531.

53. Maxfield, F. R. (1982). Weak bases and ionophores rapidly and reversibly raise the $\mathrm{pH}$ of endocytic vesicles in cultured mouse fibroblasts. J . Cell. Biol. 95, 676-681.

54. Kehle, T., and Herzog, V. (1989). A colloidal gold labeling technique for the direct determination of the surface area of eukaryotic cells. Eur. J . Cell. Biol. 48, 19-26.

55. Kaplan, J ., and Keogh, E. A. (1981). Analysis of the effect of amines on inhibition of receptor-mediated and fluid-phase pinocytosis in rabbit alveolar macrophages. Cell 24, 925-932.

56. Stoorvogel, W., Oorschot, V., and Geuze, H. J . (1996). A novel class of clathrin-coated vesicles budding from endosomes. J. Cell. Biol. 132, 21-33.

57. Rybin, V., Ullrich, O., Rubino, M., Alexandrov, K., Simon, I., Seabra, M. C., Goody, R., and Zerial, M. (1996). GTPase activity of Rab5 acts as a timer for endocytic membrane fusion. Nature 383, 266-269.

58. Silvestri, M., Oddera, S., Eftimiadi, C., and Rossi, G. A. (1995). Azithromycin induces in vitro a time-dependent increase in the intracellular killing of Staphylococcus aureus by human poly- 
morphonuclear leucocytes without damaging phagocytes. J . Antimicrob. Chemother. 36, 941-950.

59. Fietta, A., Merlini, C., and Gialdroni, G. G. (1997). Inhibition of intracellular growth of Staphylococcus aureus by exposure of infected human monocytes to clarithromycin and azithromycin. J . Chemother. 9, 17-22.

60. Carlier, M. B., Garcia-Luque, I., Montenez, J. P., Tulkens, P. M., and Piret, J . (1994). Accumulation, release and subcellular localization of azithromycin in phagocytic and non-phagocytic cells in culture. Int. J . Tissue React. 16, 211-220.

61. Tartakoff, A. M. (1983). Perturbation of vesicular traffic with the carboxylic ionophore monensin. Cell 32, 1026-1028.

62. Stoorvogel, W., Geuze, H. J ., and Strous, G. J . (1987). Sorting of endocytosed transferrin and asialoglycoprotein occurs immediately after internalization in HepG2 cells. J . Cell. Biol. 104, 1261-1268.

63. Octave, J. N., Schneider, Y. J ., Hoffmann, P., Trouet, A., and Crichton, R. R. (1982). Transferrin uptake by cultured rat embryo fibroblasts. The influence of Iysosomotropic agents, iron chelators and colchicine on the uptake of iron and transferrin. Eur. J . Biochem. 123, 235-240.

64. Aniento, F., Gu, F., Parton, R. G., and Gruenberg, J . (1996). An endosomal beta COP is involved in the $\mathrm{pH}$-dependent formation of transport vesicles destined for late endosomes. J . Cell. Biol. 133, 29- 41.

65. Bond, J . C., Lundin, J . E., and Schwartz, S. L. (1975). Procaine amide-induced vacuolation in macrophages and effects on endocytic activity. Toxicol. Appl. Pharmacol. 31, 93-99.

66. Desjardins, M., Huber, L. A., Parton, R. G., and Griffiths, G. (1994). Biogenesis of phagolysosomes proceeds through a sequential series of interactions with the endocytic apparatus. J. Cell. Biol. 124, 677-688.

67. Besterman, J . M., and Low, R. B. (1983). Endocytosis: A review of mechanisms and plasma membrane dynamics. Biochem. J . 210, 1-13.

68. J ones, C. J ., and J ayson, M. I. (1984). Chloroquine: I ts effect on leucocyte auto- and heterophagocytosis. Ann. Rheum. Dis. 43, 205-212.

69. Antoni, F., Hrabak, A., and Csuka, I. (1986). Effect of emetine and chloroquine on phagocytic processes of rat macrophages. Biochem. Pharmacol. 35, 2869-2874.

70. Botelho, R. J ., Hackam, D. J ., Schreiber, A. D., and Grinstein, S. (2000). Role of COPI in phagosome maturation. J . Biol. Chem. 275, 15717-15727.

71. Marsh, M., Wellsteed, J ., Kern, H., Harms, E., and Helenius, A. (1982). Monensin inhibits Semliki Forest virus penetration into culture cells. Proc. Natl. Acad. Sci. USA 79, 5297-5301.

72. Umata, T., Moriyama, Y., Futai, M., and Mekada, E. (1990). The cytotoxic action of diphtheria toxin and its degradation in intact Vero cells are inhibited by bafilomycin Al, a specific inhibitor of vacuolar-type H(+)-ATPase. J . Biol. Chem. 265, 21940-21945.

73. McNiven, M. A. (1998). Dynamin: A molecular motor with pinchase action. Cell 94, 151-154.

74. Duclos, S., Diez, R., Garin, J., Papadopoulou, B., Descoteaux, A., Stenmark, H., and Desjardins, M. (2000). Rab5 regulates the kiss and run fusion between phagosomes and endosomes and the acquisition of phagosome leishmanicidal properties in RAW 264.7 macrophages. J . Cell. Sci. 113, 3531-3541.
75. Roberts, R. L., Barbieri, M. A., Ullrich, J., and Stahl, P. D. (2000). Dynamics of rab5 activation in endocytosis and phagocytosis. J . Leukocyte Biol. 68, 627- 632.

76. Daro, E., Sheff, D., Gomez, M., Kreis, T., and Mellman, I. (1997). Inhibition of endosome function in $\mathrm{CHO}$ cells bearing a temperature-sensitive defect in the coatomer (COPI) component epsilon-COP. J . Cell. Biol. 139, 1747-1759.

77. Gu, F., Aniento, F., Parton, R. G., and Gruenberg, J . (1997). Functional dissection of COP-1 subunits in the biogenesis of multivesicular endosomes. J . Cell. Biol. 139, 1183-1195.

78. Draye, J. P., Courtoy, P. J ., Quintart, J ., and Baudhuin, P. (1988). A quantitative model of traffic between plasma membrane and secondary Iysosomes: Evaluation of inflow, lateral diffusion, and degradation. J . Cell. Biol. 107, 2109-2115.

79. Mukherjee, S., and Maxfield, F. R. (2000). Role of membrane organization and membrane domains in endocytic lipid trafficking. Traffic 1, 203-211.

80. van Deurs, B., Petersen, O. W., Olsnes, S., and Sandvig, K. (1989). The ways of endocytosis. Int. Rev. Cytol. 117, 131-177.

81. Sandvig, K., and van Deurs, B. (1994). Endocytosis without clathrin. Trends Cell Biol. 4, 275-277.

82. Dautry-Varsat, A. (2001). In "Clathrin-Independent Endocytosis" (M. Marsh, Ed.), Frontiers in Molecular Biology, Oxford University Press, Oxford.

83. Steer, C. J ., Bisher, M., Blumenthal, R., and Steven, A. C. (1984). Detection of membrane cholesterol by filipin in isolated rat liver coated vesicles is dependent upon removal of the clathrin coat. J. Cell. Biol. 99, 315-319.

84. Farge, E., Ojcius, D. M., Subtil, A., and Dautry-Varsat, A. (1999). Enhancement of endocytosis due to aminophospholipid transport across the plasma membrane of living cells. Am. J . Physiol 276, C725-C733.

85. Rauch, C., and Farge, E. (2000). Endocytosis switch controlled by transmembrane osmotic pressure and phospholipid number asymmetry. Biophys. J . 78, 3036-3047.

86. I shiwata, H., Sato, S. B., Vertut-Doi, A., Hamashima, Y., and Miyajima, K. (1997). Cholesterol derivative of poly(ethylene glycol) inhibits clathrin-independent, but not clathrin-dependent endocytosis. Biochim. Biophys. Acta 1359, 123-135.

87. Baba, T., Rauch, C., Xue, M., Terada, N., Fujii, Y., Ueda, H., Takayama, I., Ohno, S., Farge, E., and Sato, S. B. (2001). Clathrindependent and clathrin-independent endocytosis are differentially sensitive to insertion of poly(ethylene glycol)-derivatized cholesterol in the plasma membrane. Traffic 2, 501-512.

88. Van Bambeke, F., Montenez, J. P., Piret, J ., Tulkens, P. M., Courtoy, P. J ., and Mingeot-Leclercq, M. P. (1996). Interaction of the macrolide azithromycin with phospholipids. I . Inhibition of Iysosomal phospholipase A1 activity. Eur. J . Pharmacol. 314, 203-214.

89. Sönnichsen, B., De Renzis, S., Nielsen, E., Rietdorf, J ., and Zerial, M. (2000). Distinct membrane domains on endosomes in the recycling pathway visualised by multicolor imaging of Rab4, Rab5 and Rab11. J . Cell. Biol. 149, 901-914.

90. J ahraus, A., Tjelle, T. E., Berg, T., Habermann, A., Storrie, B., Ullrich, O., and Griffiths, G. (1998). In vitro fusion of phagosomes with different endocytic organelles from J 774 macrophages. J . Biol. Chem. 273, 30379-30390.

91. Lamaze, C., Dujeancourt, A., Baba, T., Lo, C. G., Benmerah, A., and Dautry-Varsat, A. (2001). Interleukin 2 receptors and de tergent-resistant membrane domains define a clathrin-independent endocytic pathway. Mol. Cell. 7, 661- 671. 